\title{
Molecular phylogeny reveals a new genus of freshwater mussels from the Mekong River Basin (Bivalvia: Unionidae)
}

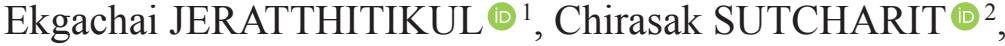 \\ Peng Bun NGOR ${ }^{0}{ }^{3}$ \& Pongpun PRASANKOK (1) ${ }^{4, *}$
}

${ }^{1}$ Animal Systematics and Molecular Ecology Laboratory, Department of Biology,

Faculty of Science, Mahidol University, Bangkok 10400, Thailand.

${ }^{2}$ Animal Systematics Research Unit, Department of Biology, Faculty of Science,

Chulalongkorn University, Bangkok 10330, Thailand.

${ }^{3}$ Faculty of Fisheries, Royal University of Agriculture, Khan Dongkor, P.O. Box 2696, Phnom Penh, 12401, Cambodia, Fisheries Administration, no. 86, Norodom Boulevard., PO Box 582, Phnom Penh, Cambodia and Wonders of the Mekong Project, c/o IFReDI, no. 86, Norodom Boulevard., PO Box 582, Phnom Penh, Cambodia.

${ }^{4}$ School of Biology, Institute of Science, Suranaree University of Technology, Nakhon Ratchasima 30000, Thailand.

*Corresponding author: prasankok@sut.ac.th ${ }^{1}$ Email: ekgachai.jer@mahidol.ac.th

${ }^{2}$ Email: chirasak.s@chula.ac.th

${ }^{3}$ Email: pengbun.ngor@gmail.com

\footnotetext{
${ }^{1}$ urn:lsid:zoobank.org:author:088AC693-052D-4EBF-AB49-E57D7A922FC8

${ }^{2}$ urn:lsid:zoobank.org:author:C2E2FA6B-A3F9-4F33-B447-B59B1BD322D4

${ }^{3}$ urn:lsid:zoobank.org:author:77BC565D-7067-46C6-8744-A0C50A6E2B3F

${ }^{4}$ urn:lsid:zoobank.org:author:3F701F9E-05D4-4597-B712-426000E72C0C
}

\begin{abstract}
A new genus of freshwater mussels (Bivalvia: Unionidae) is described from the Mekong River Basin as Namkongnaia gen. nov. The validity of the new genus is supported by its unique conchological characteristics, namely the lack of hinge dentition and elongated shells, together with its evolutionary distinctiveness as estimated by multi-locus phylogenetic analyses (mitochondrial COI and $16 \mathrm{~S}$, and nuclear $28 \mathrm{~S}$ genes). The new genus includes two lineages with deep divergence, shown by $5.10 \%$ uncorrected COI p-distance. One lineage is a type species described herein as Namkongnaia inkhavilayi gen. et sp. nov. The other is a recognized species under the name 'Pilsbryoconcha lemeslei (Morelet, 1875)'. Molecular phylogenetic analysis further shows that the new genus belongs to the tribe Pseudodontini, and evolutionarily is closely related to the genus Monodontina Conrad, 1853. However, its conchology is similar to the genus Pilsbryoconcha Simpson, 1900. Time-calibrated phylogeny suggests that the main radiation events of the tribe Pseudodontini occurred during the Late Cretaceous to the Eocene, with the divergence between the new genus and Monodontina placed in the Miocene. The discovery of new freshwater mussel taxa in this study highlights the importance of the Mekong River Basin as one of the world's biodiversity hotspots for freshwater fauna.
\end{abstract}


Keywords. Indochina, freshwater mussels, multi-locus phylogeny, new taxa, time-calibrated phylogeny.

Jeratthitikul E., Sutcharit C., Ngor P.B. \& Prasankok P. 2021. Molecular phylogeny reveals a new genus of freshwater mussels from the Mekong River Basin (Bivalvia: Unionidae). European Journal of Taxonomy 775:119-142. https://doi.org/10.5852/ejt.2021.775.1553

\section{Introduction}

The Mekong River is the longest river in Southeast Asia. The river and its tributaries cover a vast range of geographic and climatic zones that support various aquatic habitats, including the river's mainstream, mountainous streams, tributaries, floodplains, lakes, wetlands, and estuaries (Coates et al. 2003). As a result, the basin contains one of the most unique and diverse freshwater faunas on Earth (Köhler et al. 2012; Kang \& Huang 2021). Freshwater mussels (Unionidae) are of special interest for their high species diversity in the Mekong River Basin (Graf \& Cummings 2021a); furthermore, it has been hypothesized to be one of the locations of origin for mussel radiation prior to their spread worldwide (Bolotov et al. 2017a). The currently known richness of freshwater mussels in the Mekong River Basin comprises 67 species across 21 genera (Graf \& Cummings 2021a; Konopleva et al. 2021). Several of these genera and a dozen of these species were discovered within the last decade (Kongim et al. 2015; Jeratthitikul et al. 2019a; Konopleva et al. 2019, 2021; Bolotov et al. 2020; Pfeiffer et al. 2021). Moreover, 59 species are endemic to the basin, and five genera are considered monotypic, highlighting the extraordinary endemism within the tributaries (Brandt 1974; Pfeiffer et al. 2018; Bolotov et al. 2020; Graf \& Cummings 2021a; Konopleva et al. 2021). However, freshwater mussels in the Mekong River Basin are at severe risk of population decline and even extinction from the significant threats of pollution, natural habitat modification, urbanization, and overharvesting (Lopes-Lima et al. 2018; Ngor et al. 2018). Meanwhile, efforts to conserve these fragile animals in the region have made little progress due to the lack of essential data, especially regarding population size and distribution range. Their taxonomic classification also remains uncertain (Lopes-Lima et al. 2018; Zieritz et al. 2018).

Pseudodontini Frierson, 1927 represents one of the most taxonomically diverse group of freshwater mussels in Southeast Asia. At least 44 valid species are recognized, and half are distributed in the Mekong River Basin (Graf \& Cummings 2021a). This family-group name was first proposed as a subfamily by Frierson (1927) based on "large high (pseudocardinal) teeth, one in each valve", and included the genus Pseudodon Gould, 1844. Modell (1942) redefined and relocated this subfamily under Margaritiferidae Henderson, 1929 and included several genera from Asia, Europe, and North America based on the reduced pseudocardinal teeth. Subsequent revisionary works synonymized this subfamily with either Unioninae Rafinesque, 1820 (Haas 1969a, b) or Ambleminae Rafinesque, 1820 (Subba Rao 1989). Later, Brandt (1974) resurrected the subfamily rank and incorporated a second genus, Pilsbryoconcha Simpson, 1900. He also expanded diagnostic characters as "hinge teeth either completely missing or reduced to a knob-like pseudocardinal in each valve". However, all of these taxonomic opinions were based mainly on shell morphology. Molecular phylogenetic studies do not accept Brandt's (1974) classification, but instead reassign Pseudodon and Pilsbryoconcha to Gonideinae (Whelan et al. 2011; Pfeiffer \& Graf 2015). The nominal name was recently recognized as a valid tribe, Pseudodontini, within Gonideinae Ortmann, 1916 by Lopes-Lima et al. (2017) with two genera, Pseudodon and Pilsbryoconcha. The authors also suggested that the V-shaped fossette present in the inner shell at the posterior end of the hinge structure is a diagnostic character of the tribe. This classification was followed and supported by several studies using various molecular markers and techniques (Zieritz et al. 2018; Pfeiffer et al. 2019; Bolotov et al. 2020; Zieritz et al. 2020; Graf \& Cummings 2021a; Konopleva et al. 2021). Controversially, the subfamily rank has also been used by some molecular phylogenetic studies (Bolotov et al. 2017a, 2017b, 2018; Huang et al. 2019). 
Initially, Pseudodontini includes two genera, Pseudodon and Pilsbryoconcha (Lopes-Lima et al. 2017). Bolotov et al. (2017b) used multi-locus phylogenetic approaches to revise genus-level clades within this group. They revealed a polyphyletic relationship of at least five clades within Pseudodon s. lat., and applied two previously available names and erected three new genera. Hence, a total of seven genera are currently included in Pseudodontini (Bolotov et al. 2020; Graf \& Cummings 2021a). Bolotov et al. (2020) further suggested classifying Pseudodontini into a monotypic subtribe Pseudodontina and subtribe Pilsbryoconchina containing the other six genera. These two subtribes are genetically different and can be distinguished by their morphology. Shells of Pseudodontina are relatively thick, and pseudocardinal teeth are tubercle-like, rather solid, and prominent. In contrast, shells of Pilsbryoconchina are thinner, and pseudocardinal teeth are reduced or lacking (Bolotov et al. 2017b).

In the present study, we propose another new genus from the Middle Mekong River Basin belonging to Pseudodontini. This new genus has long been recognized under Pilsbryoconcha s. lat. (Haas 1920, 1969a; Brandt 1974; Graf \& Cummings 2007; Zieritz et al. 2018; Ng et al. 2020; Graf \& Cummings 2021a). We further include two species: the new species described herein, and another previously recognized as 'Pilsbryoconcha lemeslei'. The validity of these taxa is supported by their unique conchological characteristics and their evolutionary distinctiveness as estimated through multi-locus phylogenetic analyses using sequences from both mitochondrial and nuclear genes. Furthermore, the evolutionary relationship and estimation of divergence times within Pseudodontini are also discussed.

\section{Material and methods}

\section{Specimen sampling}

Animal use protocol in this study was approved by the Faculty of Science, Mahidol University Animal Care and Use Committee, SCMU-ACUC (MUSC63-026-534).

Specimens were collected by hand and euthanized by a two-step method (AVMA2020): living specimens were placed in a container filled with fresh water. Then, $95 \%(\mathrm{v} / \mathrm{v})$ ethanol was gradually added to the container starting from approximately $5 \%(\mathrm{v} / \mathrm{v})$ concentration until specimens were fully anesthetized. Specimens were moved to $70 \%(\mathrm{v} / \mathrm{v})$ ethanol to complete the process and for tissue fixation. Shells were separated from the soft body and were then gently cleaned to remove residual tissues. Tissues from the foot and/or mantle were cut and preserved in $95 \%(\mathrm{v} / \mathrm{v})$ ethanol at $-20^{\circ} \mathrm{C}$ for DNA extraction. The other remaining soft parts were preserved in $70 \%(\mathrm{v} / \mathrm{v})$ ethanol for anatomical study and kept together with their shells to serve as vouchers.

Shell morphology was compared among specimens, the type series, and photographs from museum collections available on the online database (i.e., MUSSELp Database; Graf \& Cummings 2021b). Shell comparisons were done based on shell shape, shell size, umbo position, teeth, and adductor muscle scars. Shell length, height, and width were measured using a digital Vernier calliper $( \pm 0.01 \mathrm{~mm})$. Anatomical characteristics, i.e., excurrent and incurrent aperture, labial palps, and gills, were examined under a stereomicroscope.

\section{Abbreviations used in the text}

$\begin{array}{lll}\mathrm{AICc} & = & \text { Akaike Information Criterion } \\ \mathrm{BI} & = & \text { Bayesian inference } \\ \mathrm{BS} & = & \text { Bootstrap support } \\ \mathrm{BPP} & = & \text { Bayesian posterior probability } \\ \mathrm{ESS} & = & \text { Effective Sample Sizes } \\ \mathrm{HPD} & = & \text { Highest posterior density interval } \\ \text { MCC } & = & \text { Maximum clade credibility }\end{array}$




$\begin{array}{lll}\text { MC-MCMC } & = & \text { Metropolis-coupled Markov chain Monte Carlo } \\ \text { ML } & = & \text { Maximum likelihood } \\ \text { Mya } & = & \text { Million of years ago }\end{array}$

\section{Acronyms}

$\begin{array}{lll}\text { ANSP } & = & \text { Academy of Natural Sciences, Philadelphia, USA } \\ \text { BMNH } & = & \text { Natural History Museum, London, UK } \\ \text { CUMZ } & = & \text { Chulalongkorn University Museum of Zoology, Bangkok, Thailand } \\ \text { MCZ } & = & \text { Museum of Comparative Zoology, Cambridge, USA } \\ \text { MNHN } & = & \text { Muséum national d'Histoire naturelle, Paris, France } \\ \text { MUMNH } & = & \text { Mahidol University Museum of Natural History, Bangkok, Thailand } \\ \text { SMF } & = & \text { Forschungsinstitut und Naturmuseum Senckenberg, Frankfurt a. M., Germany } \\ \text { USNM } & = & \text { National Museum of Natural History, Washington, USA }\end{array}$

\section{Molecular analysis}

Total genomic DNA was extracted from small pieces of foot or mantle tissue using a DNA NucleoSpin ${ }^{\circledR}$ extraction kit for animal tissue (MACHEREY-NAGEL, Germany) following the standard procedure of the manual. Fragments of the mitochondrial cytochrome c oxidase subunit I (COI) and the $16 \mathrm{~S}$ small ribosomal RNA (16S) genes, and the nuclear 28S ribosomal RNA gene (28S) were amplified by polymerase chain reactions (PCR). Primers used for the COI gene were LCO1490 and HCO2198 (Folmer et al. 1994); for 16S gene were 16sar-L-myt and 16Sbr-H-myt (Lydeard et al. 1996), and for 28S gene were $\mathrm{C} 1$ and D2 (Jovelin \& Justine 2001). Thermal cycling was started at $94^{\circ} \mathrm{C}$ for 3 min; followed by 35 cycles of $94^{\circ} \mathrm{C}$ for $30 \mathrm{~s}$; annealing at $48^{\circ} \mathrm{C}$ for COI, $46^{\circ} \mathrm{C}$ for $16 \mathrm{~S} \mathrm{rRNA}$, and $58^{\circ} \mathrm{C}$ for $28 \mathrm{~S}$ rRNA, for $60 \mathrm{~s}$; extension at $72^{\circ} \mathrm{C}$ for $90 \mathrm{~s}$; then a final $72^{\circ} \mathrm{C}$ for $5 \mathrm{~min}$. Amplicons were purified using a MicroSpin purification kit (Qiagen, USA). Each amplicon was bi-directionally sequenced using the same primers used for amplification on the ABI 3730XL DNA Analyzer (BIONEER, Republic of Korea). The derived consensus nucleotide sequences newly obtained in this study were deposited in the GenBank database under accession numbers MZ822395-MZ822416 for COI, MZ822895-MZ822916 for 16S and MZ822917-MZ822938 for 28S (Table 1).

\section{Phylogenetic analyses}

Phylogenetic analyses were based on 55 sequences covering all genera from Pseudodontini. Sequences from other tribes were used as outgroups (Table 1). The details of taxon sampling used in phylogenetic analysis are shown in Table 1. Sequence alignments were generated using the MUSCLE option as implemented in MEGA ver. 7.0.26 (Kumar et al. 2016). The final concatenated alignment used in phylogenetic tree construction contained $1967 \mathrm{bp}$ : $660 \mathrm{bp}$ of COI, 501 of 16S, and $806 \mathrm{bp}$ of 28S.

The best-fit evolutionary model for each gene and gene partition was calculated by PartitionFinder2 ver. 2.3.4 (Lanfear et al. 2016), based on the corrected Akaike Information Criterion (AICc) and using a heuristic search algorithm. The program suggested dividing the concatenated dataset into five partitions, consisting of partitions for $16 \mathrm{~S}$ and $28 \mathrm{~S}$ genes and for each of three codon positions of the COI gene. The best-fit model was GTR $+\mathrm{I}+\mathrm{G}$ for the first codon position of COI, $16 \mathrm{~S}$, and $28 \mathrm{~S}$; F81+I for the second codon position of COI; and GTR $+\mathrm{G}$ for the third codon position of the COI gene. This partition setting was used in subsequent Bayesian inference (BI) analysis. The BI analysis was carried out by running two runs of 10 million generations of Metropolis-coupled Markov chain Monte Carlo (MCMCMC) in MrBayes ver. 3.2 (Ronquist et al. 2012). Each MCMC run consisted of two sets of three heated chains and one cold chain. Each run used a random tree as starting tree and collected a sampling tree every $1000^{\text {th }}$ generations. The first $25 \%$ of the obtained sampling trees were discarded as burnin. Maximum likelihood analysis (ML) was performed through 1000 ML bootstrap replicates using 
Table 1 (continued on next two pages). Voucher ID, locality information, and GenBank accession numbers for specimens used in phylogenetic analysis. Those which are marked with * are newly sequenced in this study.

\begin{tabular}{|c|c|c|c|c|c|}
\hline \multirow[b]{2}{*}{ Taxa } & \multirow[b]{2}{*}{ VoucherID } & \multirow[b]{2}{*}{ Localities } & \multicolumn{3}{|c|}{ GenBank accession } \\
\hline & & & $\mathrm{COI}$ & $16 S$ & $28 \mathrm{~S}$ \\
\hline \multicolumn{6}{|c|}{ UNIONIDAE Rafinesque, 1820} \\
\hline \multicolumn{6}{|c|}{ GONIDEINAE Ortmann, 1916} \\
\hline \multicolumn{6}{|c|}{ PSEUDODONTINI Frierson, 1927} \\
\hline \multicolumn{6}{|c|}{ Ingroups } \\
\hline \multirow{4}{*}{$\begin{array}{l}\text { Namkongnaia } \\
\text { inkhavilayi gen. et sp. nov }\end{array}$} & MUMNH-UNI2831 & Laos: Mekong & MZ822395* & MZ822895* & MZ822917* \\
\hline & MUMNH-UNI2832 & River Basin, local & MZ822396* & MZ822896* & MZ822918* \\
\hline & MUMNH-UNI2833 & market near Xe & MZ822397* & MZ822897* & MZ822919* \\
\hline & MUMNH-UNI2834 & Bangfai River & MZ822398* & MZ822898* & MZ822920* \\
\hline \multirow{6}{*}{$\begin{array}{l}\text { Namkongnaia lemeslei } \\
\text { (Morelet, } 1875 \text { gen. et } \\
\text { comb. nov.) }\end{array}$} & MUMNH-UNI2825 & Cambodia: Tonle & MZ822399* & MZ822899* & MZ822921* \\
\hline & MUMNH-UNI2826 & Sap Basin, Kam- & MZ822400* & MZ822900* & MZ822922* \\
\hline & MUMNH-UNI2827 & pong Kdei River & MZ822401* & MZ822901* & MZ822923* \\
\hline & MUMNH-UNI2828 & & MZ822402* & MZ822902* & MZ822924* \\
\hline & MUMNH-UNI2829 & & MZ822403* & MZ822903* & MZ822925* \\
\hline & MUMNH-UNI2830 & & MZ822404* & MZ822904* & MZ822926* \\
\hline $\begin{array}{l}\text { Monodontina vondem- } \\
\text { buschiana (Lae, } 1840 \text { ) }\end{array}$ & BIV1822 & Malaysia & MK994774 & MK994774 & $\mathrm{n} / \mathrm{a}$ \\
\hline $\begin{array}{l}\text { Monodontina mekongi } \\
\text { Bolotov et al., } 2020\end{array}$ & RMBH biv0122 & $\begin{array}{l}\text { Thailand: Mekong } \\
\text { River Basin, Phong } \\
\text { River }\end{array}$ & KX865861 & KX865632 & KX865733 \\
\hline $\begin{array}{l}\text { Monodontina laosica } \\
\text { Bolotov et al., } 2020\end{array}$ & UMMZ 304650 & $\begin{array}{l}\text { Laos: Mekong } \\
\text { River Basin, } \\
\text { tributary of the } \\
\text { Vang Ngao River }\end{array}$ & KP795029 & KP795052 & $\mathrm{n} / \mathrm{a}$ \\
\hline $\begin{array}{l}\text { Monodontina } \\
\text { cambodiensis (Petit, 1865) }\end{array}$ & $\mathrm{n} / \mathrm{a}$ & Thailand & KX822660 & $\mathrm{n} / \mathrm{a}$ & KX822616 \\
\hline $\begin{array}{l}\text { Monodontina lenyanensis } \\
\text { Bolotov et al., } 2020\end{array}$ & RMBH biv0628_2 & $\begin{array}{l}\text { Myanmar: Lenya } \\
\text { River Basin, } \\
14 \text { Mile Stream }\end{array}$ & MN275055 & MN307246 & MN307187 \\
\hline $\begin{array}{l}\text { Bineurus mouhotii } \\
\text { (Lea, 1863) }\end{array}$ & RMBH biv0182_2 & $\begin{array}{l}\text { Laos: Mekong } \\
\text { River Basin, } \\
\text { Nam Long River }\end{array}$ & KX865876 & KX865647 & KX865747 \\
\hline \multirow{4}{*}{$\begin{array}{l}\text { Bineurus exilis } \\
\text { (Morelet, 1866) }\end{array}$} & MUMNH-UNI2660 & Cambodia: Tonle & MZ822405* & MZ822905* & MZ822927* \\
\hline & MUMNH-UNI2728 & Sap Basin, Sangker & MZ822406* & MZ822906* & MZ822928* \\
\hline & MUMNH-UNI2730 & River, Battambang & MZ822407* & MZ822907* & MZ822929* \\
\hline & RMBH biv0474_1 & $\begin{array}{l}\text { Thailand: Mekong } \\
\text { River Basin, Mun } \\
\text { River, upstream of } \\
\text { upper reservoir }\end{array}$ & MN275052 & MN307243 & MN307184 \\
\hline $\begin{array}{l}\text { Thaiconcha callifera } \\
\text { (Martens, 1860) }\end{array}$ & RMBH biv0120_3 & $\begin{array}{l}\text { Thailand: Mekong } \\
\text { River Basin, Phong } \\
\text { River }\end{array}$ & KX865865 & KX865636 & KX865737 \\
\hline $\begin{array}{l}\text { Sundadontina cumingii } \\
\text { (Lea, 1850) }\end{array}$ & $\mathrm{X} 115$ & Malaysia & KX051295 & $\mathrm{n} / \mathrm{a}$ & $\mathrm{n} / \mathrm{a}$ \\
\hline $\begin{array}{l}\text { Sundadontina tumida } \\
\text { (Morelet, 1866) }\end{array}$ & UMMZ 304349 & $\begin{array}{l}\text { Cambodia: Mekong } \\
\text { River Basin }\end{array}$ & KP795027 & KF011261 & KP795010 \\
\hline
\end{tabular}


Table 1 (continued). Voucher ID, locality information, and GenBank accession numbers for specimens used in phylogenetic analysis. Those which are marked with * are newly sequenced in this study.

\begin{tabular}{|c|c|c|c|c|c|}
\hline \multirow[b]{2}{*}{ Taxa } & \multirow[b]{2}{*}{ VoucherID } & \multirow[b]{2}{*}{ Localities } & \multicolumn{3}{|c|}{ GenBank accession } \\
\hline & & & COI & $16 \mathrm{~S}$ & $28 \mathrm{~S}$ \\
\hline $\begin{array}{l}\text { Sundadontina brandti } \\
\text { Bolotov et al., } 2020\end{array}$ & RMBH biv0475_2 & $\begin{array}{l}\text { Thailand: Mekong } \\
\text { River Basin, Mun } \\
\text { River }\end{array}$ & MN275058 & MN307249 & MN307190 \\
\hline $\begin{array}{l}\text { Sundadontina taskaevi } \\
\text { Bolotov et al., } 2020\end{array}$ & RMBH biv0475_1 & $\begin{array}{l}\text { Thailand: Mekong } \\
\text { River Basin, Mun } \\
\text { River }\end{array}$ & MN275061 & MN307251 & MN307192 \\
\hline $\begin{array}{l}\text { Nyeinchanconcha } \\
\text { nyeinchani } \\
\text { Bolotov et al., } 2020\end{array}$ & UMMZ 304648 & $\begin{array}{l}\text { Laos: Mekong } \\
\text { River Basin, Nam } \\
\text { Phiat River }\end{array}$ & KP795025 & KP795050 & KP795008 \\
\hline \multirow{5}{*}{$\begin{array}{l}\text { Pilsbryoconcha exilis } \\
\text { (Lea, 1838) }\end{array}$} & MUMNH-UNI2481 & Indonesia: Java & MZ822408* & MZ822908* & MZ8229230* \\
\hline & MUMNH-UNI2482 & Basin, Bogor Bota- & MZ822409* & MZ822909* & MZ8229231* \\
\hline & MUMNH-UNI2483 & nical Gardens & MZ822410* & MZ822910* & MZ8229232* \\
\hline & MUMNH-UNI0290 & $\begin{array}{l}\text { Thailand: Chao } \\
\text { Phraya River } \\
\text { Basin, Pasak River, } \\
\text { Phetchabun }\end{array}$ & MZ822411* & MZ822911* & MZ8229233* \\
\hline & MUMNH-UNI2779 & $\begin{array}{l}\text { Thailand: Chao } \\
\text { Phraya River Basin, } \\
\text { Sakae Krang River, } \\
\text { Uthai Thani }\end{array}$ & MZ822412* & MZ822912* & MZ8229234* \\
\hline \multirow[t]{4}{*}{$\begin{array}{l}\text { Pilsbryoconcha } \\
\text { linguaeformis Morelet, } \\
1875\end{array}$} & MUMNH-UNI2625 & $\begin{array}{l}\text { Cambodia: Tonle } \\
\text { Sap Basin, Tonle } \\
\text { Sap Lake, Boeng } \\
\text { Tonle Chhma }\end{array}$ & MZ822413* & MZ822913* & MZ8229235* \\
\hline & MUMNH-UNI2624 & $\begin{array}{l}\text { Cambodia: Tonle } \\
\text { Sap Basin, Tonle } \\
\text { Sap Lake, Chhnok } \\
\text { Tru }\end{array}$ & MZ822414* & MZ822914* & MZ8229236* \\
\hline & MUMNH-UNI2741 & $\begin{array}{l}\text { Cambodia: Tonle } \\
\text { Sap Basin, Tonle } \\
\text { Sap Lake open area }\end{array}$ & MZ822415* & MZ822915* & MZ8229237* \\
\hline & MUMNH-UNI2698 & $\begin{array}{l}\text { Thailand: Bang Pa- } \\
\text { kong River Basin, } \\
\text { Hanuman River, } \\
\text { Prachin Buri }\end{array}$ & MZ822416* & MZ822916* & MZ8229238* \\
\hline $\begin{array}{l}\text { Pilsbryoconcha 'lemeslei' } \\
\text { sensu Bolotov, } 2020\end{array}$ & $\mathrm{n} / \mathrm{a}$ & Vietnam & KX822657 & $\mathrm{n} / \mathrm{a}$ & $\mathrm{n} / \mathrm{a}$ \\
\hline $\begin{array}{l}\text { Pseudodon cf. inoscularis } \\
\text { (Gould, 1844) }\end{array}$ & RMBH biv0110_5 & $\begin{array}{l}\text { Myanmar: } \\
\text { Ayeyarwady River } \\
\text { Basin, a tributary of } \\
\text { Lake Indawgyi }\end{array}$ & KX865858 & KX865629 & KX865730 \\
\hline $\begin{array}{l}\text { Pseudodon bogani } \\
\text { Bolotov et al., } 2017\end{array}$ & RMBH biv0241_4 & $\begin{array}{l}\text { Myanmar: Sittaung } \\
\text { River Basin, Kanni } \\
\text { River }\end{array}$ & MF352216 & MF352290 & MF352348 \\
\hline $\begin{array}{l}\text { Pseudodon manueli Kono- } \\
\text { pleva et al., } 2017\end{array}$ & RMBH biv0246_1 & $\begin{array}{l}\text { Myanmar: Sittaung } \\
\text { River Basin, } \\
\text { Pyowne River }\end{array}$ & & MF352300 & MF352358 \\
\hline
\end{tabular}


JERATTHITIKUL E. et al., New freshwater mussels (Bivalvia: Unionidae) from the Mekong River Basin

Table 1 (continued). Voucher ID, locality information, and GenBank accession numbers for specimens used in phylogenetic analysis. Those which are marked with * are newly sequenced in this study.

\begin{tabular}{|c|c|c|c|c|c|}
\hline \multirow[b]{2}{*}{ Taxa } & \multirow[b]{2}{*}{ VoucherID } & \multirow[b]{2}{*}{ Localities } & \multicolumn{3}{|c|}{ GenBank accession } \\
\hline & & & $\mathrm{COI}$ & $16 S$ & $28 S$ \\
\hline $\begin{array}{l}\text { Pseudodon salwenianus } \\
\text { (Gould, 1844) }\end{array}$ & RMBH biv0639_1 & $\begin{array}{l}\text { Myanmar: Salween } \\
\text { River Basin, } \\
\text { unnamed stream }\end{array}$ & MN275037 & MN307237 & MN307178 \\
\hline $\begin{array}{l}\text { Pseudodon kayinensis } \\
\text { Bolotov et al., } 2020\end{array}$ & RMBH biv0618_3 & $\begin{array}{l}\text { Myanmar: Ataran } \\
\text { River Basin, } \\
\text { Winyaw River }\end{array}$ & MN275045 & MN307240 & MN307181 \\
\hline \multicolumn{6}{|l|}{ Outgroups } \\
\hline \multicolumn{6}{|l|}{ GONIDEINI Ortmann, 1916} \\
\hline $\begin{array}{l}\text { Sinosolenaia carinata } \\
\text { (Heude, 1877) }\end{array}$ & $\mathrm{n} / \mathrm{a}$ & China & KX822669 & NC_023250 & KX822626 \\
\hline $\begin{array}{l}\text { Gonidea angulata } \\
\text { (Lea, 1838) }\end{array}$ & RMBH biv0294_1 & $\begin{array}{l}\text { USA: Okanagan } \\
\text { Lake }\end{array}$ & MN402615 & MN396726 & MN396722 \\
\hline $\begin{array}{l}\text { Leguminaia wheatleyi } \\
\text { (Lea, 1862) }\end{array}$ & RMBH biv0177_7 & $\begin{array}{l}\text { Turkey: Karasu } \\
\text { River }\end{array}$ & MN402614 & MN396725 & MN396721 \\
\hline \multicolumn{6}{|c|}{ LAMPROTULINI Modell, 1942} \\
\hline $\begin{array}{l}\text { Lamprotula leaii } \\
\text { (Griffith \& Pidgeon, 1833) }\end{array}$ & RMBH biv0200_1 & Vietnam & MN402616 & MN396727 & MN396723 \\
\hline $\begin{array}{l}\text { Potomida littoralis } \\
\text { (Cuvier, 1798) }\end{array}$ & RMBH biv0177_10 & $\begin{array}{l}\text { Turkey: Karasu } \\
\text { River }\end{array}$ & MN402617 & MN396728 & MN396724 \\
\hline $\begin{array}{l}\text { Pronodularia japanensis } \\
\text { (Lea, 1859) }\end{array}$ & NCSM 27183 & Japan & KX822659 & AB055625 & KX822615 \\
\hline \multicolumn{6}{|c|}{ CHAMBERLAINIINI Bogan, Froufe \& Lopes-Lima in Lopes-Lima et al. 2017} \\
\hline $\begin{array}{l}\text { Chamberlainia hainesiana } \\
\text { (Lea, 1856) }\end{array}$ & BIV46 & Thailand & NC044110 & $\mathrm{n} / \mathrm{a}$ & KX822592 \\
\hline $\begin{array}{l}\text { Sinohyriopsis cumingii } \\
\text { (Lea, 1852) }\end{array}$ & $\begin{array}{l}\text { 16_NCU_XPWU_ } \\
\text { SU177 }\end{array}$ & China & NC011763 & NC011763 & MG595614 \\
\hline \multicolumn{6}{|c|}{ RECTIDENTINI Modell, 1942} \\
\hline $\begin{array}{l}\text { Hyriopsis bialata } \\
\text { Simpson, } 1900\end{array}$ & BIV1774 & $\begin{array}{l}\text { Malaysia: Pahang } \\
\text { River, Pahang }\end{array}$ & KX051274 & MT993644 & MT993697 \\
\hline $\begin{array}{l}\text { Ensidens ingallsianus } \\
\text { (Lea, 1852) }\end{array}$ & MUMNH-UNI0074 & $\begin{array}{l}\text { Thailand: Chao } \\
\text { Phraya River Basin, } \\
\text { Song River, Phrae }\end{array}$ & MT993541 & MT993687 & MT993739 \\
\hline $\begin{array}{l}\text { Rectidens sumatrensis } \\
\text { (Dunker, 1852) }\end{array}$ & RMBH biv0211_1 & $\begin{array}{l}\text { Malaysia: Perak } \\
\text { River, Perak }\end{array}$ & MF352288 & $\mathrm{n} / \mathrm{a}$ & MF352405 \\
\hline \multicolumn{6}{|c|}{ CONTRADENTINI Modell, 1942} \\
\hline $\begin{array}{l}\text { Lens contradens } \\
\text { (Lea, 1838) }\end{array}$ & MUMNH-UNI0197 & $\begin{array}{l}\text { Thailand: Chao } \\
\text { Phraya River Basin, } \\
\text { Sakae Krang River, } \\
\text { Uthai Thani }\end{array}$ & MG581991 & MT993693 & MT993745 \\
\hline $\begin{array}{l}\text { Physunio superbus } \\
\text { (Lea, 1843) }\end{array}$ & MUMNH-UNI0199 & $\begin{array}{l}\text { Thailand: Chao } \\
\text { Phraya River Basin, } \\
\text { Chao Phraya River, } \\
\text { Nakhon Sawan }\end{array}$ & MG582020 & MT993689 & MT993741 \\
\hline $\begin{array}{l}\text { Trapezoideus foliaceus } \\
\text { (Gould, 1843) }\end{array}$ & $\begin{array}{l}\text { UF507879 (=ICH- } \\
02104)\end{array}$ & $\begin{array}{l}\text { Thailand: Mae } \\
\text { Klong River Basin, } \\
\text { Pachee River }\end{array}$ & MH345984 & MH346024 & MH346004 \\
\hline
\end{tabular}


RAxML ver. 8.2.10 (Stamatakis 2014) and with the GTRGAMMA model. Both BI and ML analyses were conducted at the San Diego Supercomputer Center through the online CIPRES Science Gateway (Miller et al. 2010).

Average genetic distances among taxa were estimated for the COI data set using uncorrected pairwise genetic distances as implemented in MEGA ver. 7.0.26 (Kumar et al. 2016).

\section{Estimation of divergence times}

Divergence time was estimated by constructing a time-calibrated phylogeny as implemented in BEAST ver. 2.6.1 (Bouckaert et al. 2019) through the online CIPRES Science Gateway (Miller et al. 2010). The same multi-locus dataset as for phylogenetic analyses was used. The external COI evolutionary rate of $0.265 \pm 0.06 \%$ substitutions per site per million years as previously estimated for Unionidae (Fonseca et al. 2016) was applied for tree dating. The use of evolutionary rates taken from literature without calibration by fossils or geological events may give inappropriate results and should be interpreted with caution. Nevertheless, a previous study that used this evolutionary rate showed reliable estimation results (Bolotov et al. 2020), which were largely congruent with those estimated from mitogenomic data (Fonseca et al. 2016) and those using fossil data as calibration points (Bolotov et al. 2017a). The evolutionary model for each partition was set separately, following the suggestion of jModelTest ver. 2.1.10 (Darriba et al. 2012). The evolutionary rate was implemented only for the COI partition and was set as estimated for other partitions. The analyses were run using a lognormal relaxed clock algorithm (Drummond et al. 2006). A random tree generated from the COI dataset with the Yule speciation process was used as a tree prior. Two independent MCMCs were run for 50 million generations, and tree sampling was collected every $1000^{\text {th }}$ generation. The output files were checked for convergence diagnostics and Effective Sample Sizes (ESS) using Tracer ver. 1.7 (Rambaut et al. 2018). The effective sample size (ESS) values were greater than 1500 for all parameters. Results from two independent runs were compiled with 25\% burn-in using LogCombiner ver. 2.6.2 (Bouckaert et al. 2019) and then summarized for the maximum clade credibility (MCC) tree in TreeAnnotator ver. 2.6.2 (Bouckaert et al. 2019).

\section{Results}

\section{Phylogenetic analysis and divergence time estimation}

Both ML and BI analyses returned similar topologies. Therefore, only the tree topology from ML is presented in Fig.1. All of the genera in Pseudodontini are recovered as highly supported clades, with 95-100\% bootstrap support (BS) values for ML and Bayesian posterior probability (BPP) of 1 for BI, except Sundadontina Bolotov et al., 2020, which shows poor support $(\mathrm{BS}=32 \%$, BPP $=0.79)$. The pairwise distance analysis also reveals a large genetic distance among these genera, with $10.65-13.59 \%$ uncorrected COI p-distance (Table 2).

Among available clades, there is one highly supported clade that is distantly separated from other genera, with pairwise uncorrected COI p-distance ranging from $11.02 \%$ to $12.42 \%$. This clade shows unique morphological characteristics distinguishable from other genera. Therefore, it is described herein as Namkongnaia gen. nov. The new genus further includes two well-defined clades (BS $=99-100 \%$, BPP $=$ 0.99 ), with a deep divergence of $5.10 \%$ uncorrected COI p-distance. Both clades are morphologically distinct from each other. One clade has long been recognized under the name 'Pilsbryoconcha lemeslei' and the other is described herein. Interestingly, a sequence recognized as Pilsbryoconcha lemeslei sensu Bolotov et al. (2020) fails to group with our specimens; instead, it is placed within Pilsbryoconcha s. str. $(\mathrm{BS}=95 \%, \mathrm{BPP}=0.99)$.

The phylogenetic relationship among genera within Pseudodontini is uncertain and with poor support. Nevertheless, the phylogenetic tree reveals a monophyletic relationship among six genera 


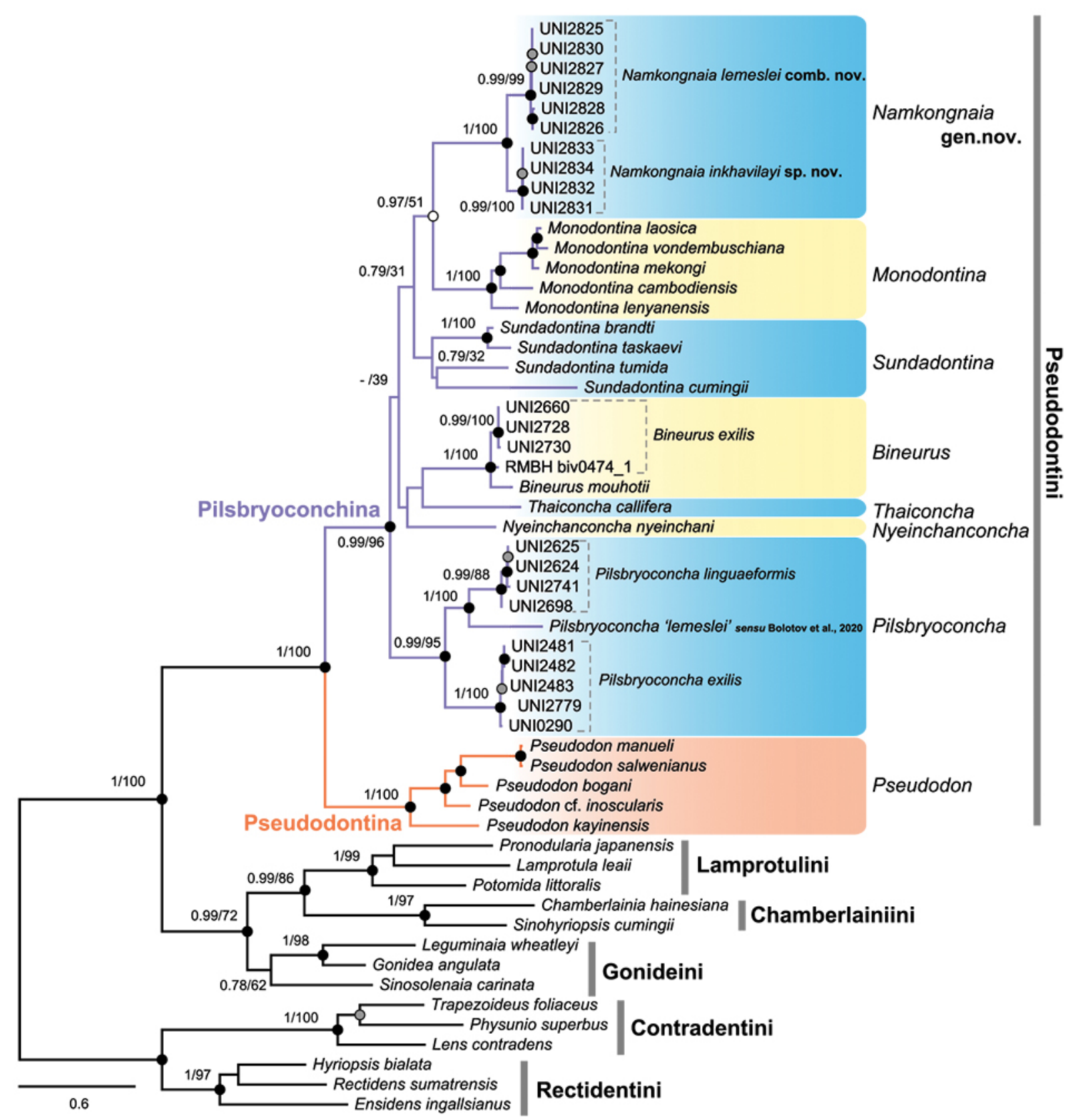

Fig. 1. Maximum likelihood (ML) tree of the subfamily Gonideinae based on the concatenated dataset of COI $+16 \mathrm{~S}+28 \mathrm{~S}$ genes. Bootstrap values from ML and posterior probabilities from Bayesian inference analysis $(\mathrm{BI})$ of the major nodes are listed as ML/BI. Nodes with posterior probabilities of BI $\geq 0.95$ and ML bootstrap support values $\geq 70$ were considered as sufficiently supported nodes (Huelsenbeck \& Hillis 1993; Larget \& Simon 1999), and are marked with black circles (supported by both BI and ML), white circles (supported only by BI), or grey circles (supported only by ML). 
in Pilsbryoconchina $(\mathrm{BS}=96 \%, \mathrm{BPP}=0.99)$ and separates them from Pseudodontina (only the genus Pseudodon currently belongs to this subtribe). The average genetic distance between these subtribes is $12.5 \%$ uncorrected COI p-distance. In addition, the new genus is suggested as a sister clade with Monodontina, although with only $0.97 \mathrm{BPP}$ support from BI.

A reconstructed time-calibrated phylogeny (based on $0.265 \pm 0.06 \%$ substitutions per site per million years of COI evolutionary rate) is shown in Fig. 2. Based on this, Pseudodontini diverged in the Late Cretaceous (mean age $=91.9$ Mya, 95\% HPD $=67.8-116.9$ Mya), while Pilsbryoconchina appears to have radiated into several genera within the Late Cretaceous to the Eocene (mean age $=70.8-49.3 \mathrm{Mya}$ ). The most recent split within Pilsbryoconchina was between this new genus and Monodontina during the Eocene (mean age $=49.3$ Mya, 95\% HPD = 35.4-63.7 Mya). The divergence between the two species of the new genus is placed in the Miocene (mean age $=17.2 \mathrm{Mya}, 95 \% \mathrm{HPD}=9.8-24.9 \mathrm{Mya}$ ). This timing is consistent with the diversification events in other genera between the Eocene to Miocene (mean age $=39.6-10.9$ Mya). Moreover, Sundadontina is recovered as polyphyletic in 'BEAST' analysis, in which Sundadontina cumingii is placed separately from other congeners.

\section{Taxonomy}

Given the results of the morphological examination and multiple lines of molecular evidence mentioned above, we thus propose describing the novel discovered clade in Pilsbryoconchina as Namkongnaia gen. nov., together with a new species from Laos. We also transfer Anodonta lemeslei Morelet, 1875 to this new genus.

Family Unionidae Rafinesque, 1820

Subfamily Gonideinae Ortmann, 1916

Tribe Pseudodontini Frierson, 1927

Subtribe Pilsbryoconchina Bolotov et al., 2017

Genus Namkongnaia gen. nov. urn:lsid:zoobank.org:act:77AD43CF-83EC-42B8-B021-A950D4E701A0

\section{Type species}

Namkongnaia inkhavilayi gen. et sp. nov., by present designation.

\section{Differential diagnosis}

The new genus is distinguished from other genera in Pseudodontini by having a narrow, elongated, and less inflated shell. It is also represented as a distinct clade in multi-locus phylogenetic analyses.

\section{Description}

Shell Medium-sized, thin, narrow and elongated, rather compressed, very inequilateral; anteriorly round; posteriorly round or somewhat pointed; umbonal area not elevated and usually eroded. Ligament very narrow. Hinge without dentition, posterior end of the hinge structure with V-shaped fossette. Anterior adductor muscle scar shallow, ovate, and fused with pedal retractor muscle scars; posterior adductor muscle scar very shallow. Excurrent aperture smooth, shorter than incurrent; incurrent with 1-2 rows of conical papillae. Gills elongated and slightly ribbed; anterior margin of inner gills slightly longer and wider than outer gills.

\section{Etymology}

The generic name "Namkongnaia" is from the word "Namkong", a name for the Mekong River used by Thai and Lao peoples, and Greek word "naiad" meaning freshwater mussels. The name of this genus thus means "freshwater mussels from Mekong River". 


\section{Distribution}

Mekong River and its tributaries in Laos, Cambodia, and Thailand (Fig. 3; Brandt 1974; Ng et al. 2020). The distribution range may include the Mae Klong River Basin in Thailand (Brandt 1974), although the taxonomic status of the specimens recorded in Brandt (1974) needs to be confirmed.

\section{Remarks}

The new genus is currently composed of two species, which are confirmed by our multi-locus molecular data. Other potential species are probably among those previously recognized under the name 'Pilsbryoconcha lemeslei' by Brandt (1974). This includes the specimens from 'Bang Pae', Mae Klong River Basin, Ratchaburi Province (USNM-786217, SMF-BR2663, and ANSP-H19041). These specimens show elongate and narrow shell, which are diagnostic characters of the genus, but differ from other species by having a minute concave ventral margin, and truncated posterior margin with a pointed posterior end. Further examination of fresh materials and DNA investigation would confirm the taxonomic status of these populations.

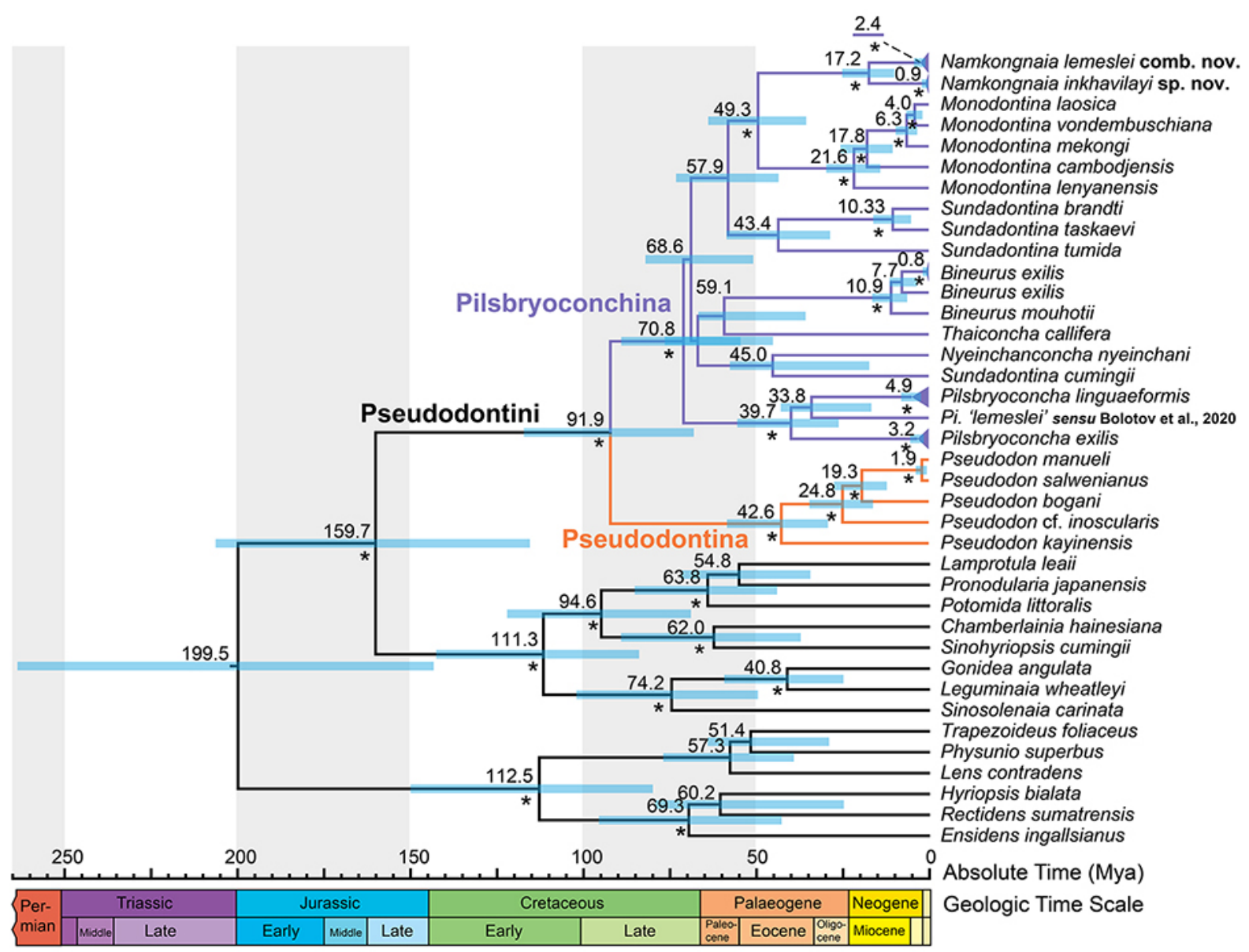

Fig. 2. Time-calibrated tree of the subfamily Gonideinae based on the concatenated alignment dataset of $\mathrm{COI}+16 \mathrm{~S}+28 \mathrm{~S}$ genes. Nodes present time estimates since the most recent common ancestor (tMRCA) in millions of years ago (Mya). Node bars indicate $95 \%$ highest posterior density interval (HPD) of the node ages. Sufficiently supported nodes (BPP $>0.95$ ) are marked with ' $*$ '. The geologic time scale is according to the Geological Society of America, 2019. 
Namkongnaia inkhavilayi gen. et sp. nov. urn:lsid:zoobank.org:act:622F7788-F0A4-449D-814A-5B49CD20B228

Figs. 3, 4A-B; Tables 1, 3

Pilsbryoconcha lemeslei - Brandt 1974: 263, pl. 18 fig. 22 (in part, only records from "Nang Rong (Prov. Burirum)", Thailand) [non Anodonta lemeslei Morelet, 1875].

\section{Etymology}

This new species is dedicated to our colleague and distinguished malacologist, Dr Khamla Inkhavilay, from the National University of Laos.

\section{Type material}

\section{Holotype}

LAOS - Kammoune Province, Bunghona Market, $7 \mathrm{~km} \mathrm{~N}$ of Xe Bangfai River; $17.13674^{\circ} \mathrm{N}$, 104.98591 ${ }^{\circ}$ E; E. Jeratthitikul, K. Wisittikoson, A. Fanka, N. Wutthituntisil and P. Prasankok leg.; sold by local people; MUMNH-UNI2831.

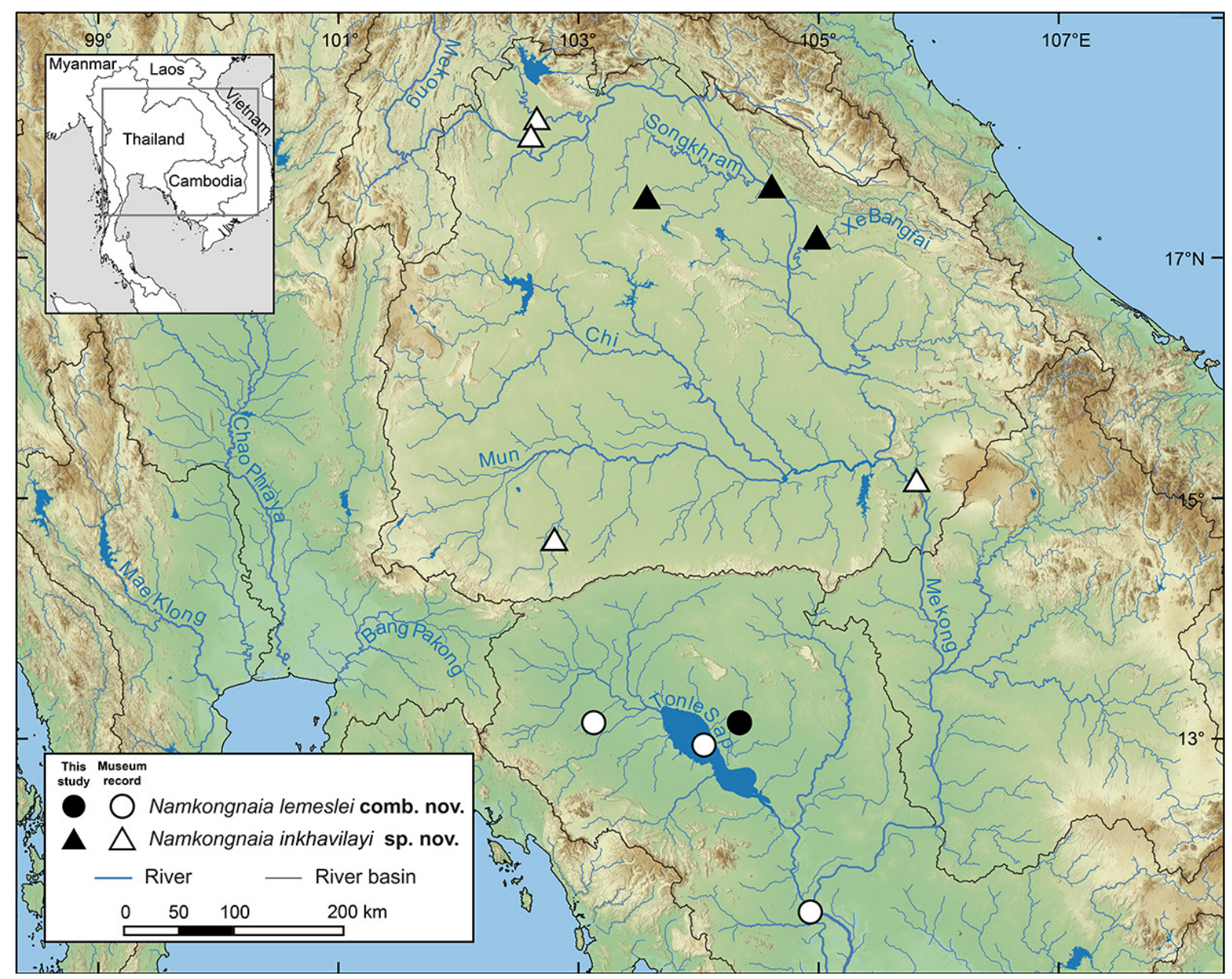

Fig. 3. Map showing distribution localities of Namkongnaia gen. nov. Boundaries of river basins follow Abell et al. (2008). 
Table 2. Average genetic divergence based on uncorrected p-distance of 660-bp COI gene fragment sequences of freshwater mussel genera in the tribe Pseudodontini ( $\% \pm$ S.E.).

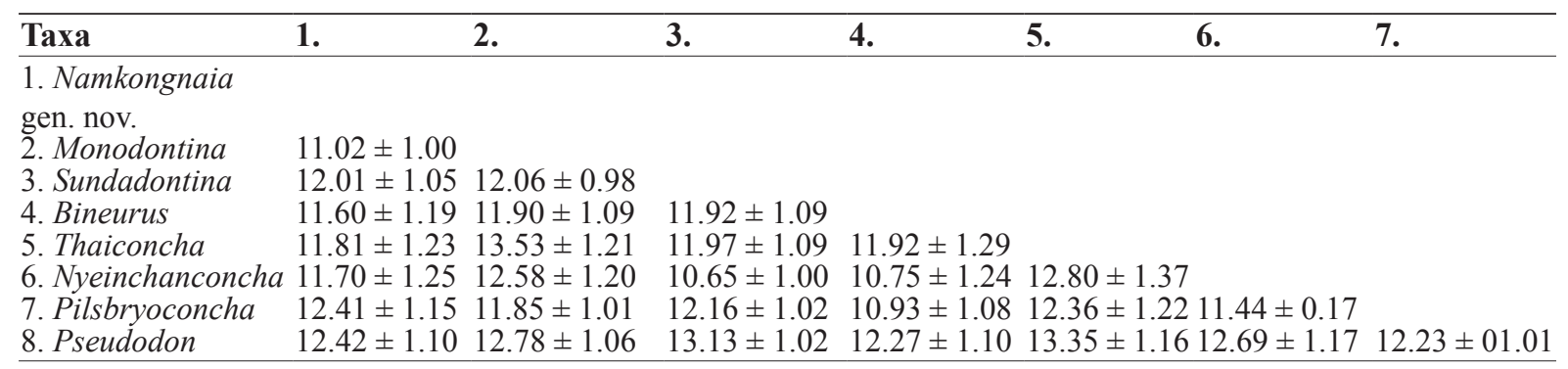

\section{Paratypes}

LAOS 5 shells; same collection data as for holotype; MUMNH-UNI2832 to UNI2835.

\section{Other material}

LAOS • 2 shells; Nong Njang, N of Vientiane; R. Brandt leg.; BMNH-MP-D262 • 1 shell; Nong Bua Thong near Vientiane; R. Brandt leg.; ANSP-H19043 • 2 shells; Nong Bua Thong near Vientiane; R. Brandt leg.; MCZ-280932 • 2 shells; Nong Bua Thong near Vientiane; R. Brandt leg.; SMF-258771 - 2 shells; Nong Bua Thong, Vientiane; R. Brandt leg.; SMF-319294 • 1 shell; Bang Jian near Vientiane; R. Brandt leg.; ANSP-H19044 • 6 shells; Nang Njang near Vientiane; MNHN-MP-3154 4 shells; Nang Njang near Vientiane; R. Brandt leg.; MNHN-MP-3157 • 3 shells; swamp near Pakse; R. Brandt leg.; SMF-225743.

THAILAND • 1 shell; Nakhon Phanom, Tha Uthen, Tha Uthen, Thuai River; $17.56221^{\circ} \mathrm{N}, 104.60890^{\circ} \mathrm{E}$; E. Jeratthitikul, K. Wisittikoson and P. Prasankok leg.; MUMNH-UNI2706 • 1 shell; Sakon Nakhon, Sawang Daen Din, Bong Tai, Songkhram River; $17.39570^{\circ}$ N, $103.30048^{\circ}$ E; E. Jeratthitikul and K. Wisittikoson leg.; MUMNH-UNI0318 • 1 shell; Buriram, Nang Rong, Huai Tadjek; R. Brandt leg.; USNM-786219 • 1 shell; Buriram, Nang Rong, Huai Tadjek; R. Brandt leg.; SMF-220822 • 4 shells; Buriram, Nang Rong; SMRL-2662 • 1 shell; Buriram, Huai Ta Djek near Nang Rong; ANSP-H19042.

\section{Description}

Shell medium-sized, length 80.9-102.2 mm, height 26.2-37.2 mm, width 13.6-19.1 mm (Table 3). Shell rather thin, narrow and elongated $(\mathrm{H} / \mathrm{L}$ ratio $=0.32-0.36)$, very inequilateral, compressed. Dorsal margin straight, anterior at the same level as posterior. Umbonal area eroded, not elevated. Anterior margin round; posterior margin elongated and rounded. Ventral margin almost straight, slightly curved upward posteriorly. Posterior ridges low, wide and obtuse, not prominent. Periostracum thin, greenish to dark brown, the eroded part coppery-brown. Shell surface with fine growth lines. Ligament very narrow. Hinge without dentition, posterior end of the hinge structure with V-shaped fossette. Anterior adductor muscle scar placed relatively far from the dorsal margin, shallow, ovate, fused with pedal retractor muscle scars; posterior adductor muscle scars very shallow, almost invisible. Pallial line very faint. Nacre whitish with cream tint near the umbo. Excurrent aperture smooth, shorter than incurrent. Incurrent with 1-2 rows of conical papillae, varying in length. Small epithelial folds form a fused bridge separating excurrent and incurrent aperture. Gills elongated and slightly ribbed. Anterior margin of inner gills slightly longer and wider than that of inner outer gills. Glochidia unknown.

\section{Distribution}

This new species appears to occur in the Lower Mekong watershed. In Laos, it was recorded from several locations near Vientiane, Kammoune, and Champasak Provinces. In Thailand, it is known from the Songkram and Mun river basins in the northeast region (Brandt 1974). 


\section{Habitat}

Specimens of the new species were bought on a local market near the Xe Bangfai River. However, specimens from the Thuai and Songkhram Rivers in Thailand were found buried in the mud substrate of still water. Brandt (1974) also reported ponds as a general habitat of this species.

\section{Remarks}

The specimens recorded by Brandt (1974) from Nang Rong, Buriram, Thailand (SMF-220822) show a shorter but wider shell and a relative rounded ventral margin. In addition, although the hinge area of this species has no dentition, the trace of a rudimentary pseudocardinal tooth is seen as a very tiny tubercle in some individuals.

\section{Namkongnaia lemeslei (Morelet, 1875) gen. et comb. nov.}

Figs 3, 5; Table 1

Anodonta lemeslei Morelet, 1875: 328, pl.14 fig. 1.

Pilsbryoconcha lemsleyi [sic] Simpson, 1900: 558.

Anodonta lemeslei - Crosse \& Fischer 1876: 333. - Morlet 1889: 167.

Pilsbryoconcha lemeslei - Simpson 1914: 244. - Haas 1920: 300, pl. 37 fig. 4.; 1969a: 382.

- Brandt 1974: 263 (in part, only records from "Aranyapratet (Prov. Prachin Buri)", Thailand).

— Graf \& Cummings 2007: 311. — Zieritz et al. 2018: 29-44. - Ng et al. 2020: 122, fig. 3j.;

— Graf \& Cummings 2021a: 22.

\section{Type material}

\section{Syntype}

CAMBODIA • 2 shells; "Cambodge, Marecages de Battambang”; Le Mesle leg.; MNHN-MP-3150.

\section{Other material}

CAMBODIA • 6 shells; Siem Reap, Chi Kraeng, Kampong Kdei, Kampong Kdei River; $13.13279^{\circ}$ N, 104.33989 E; E. Jeratthitikul, C. Sutcharit, W. Siriwut, S. Chhuoy and T.H. Ng leg.; MUMNH-UNI2825

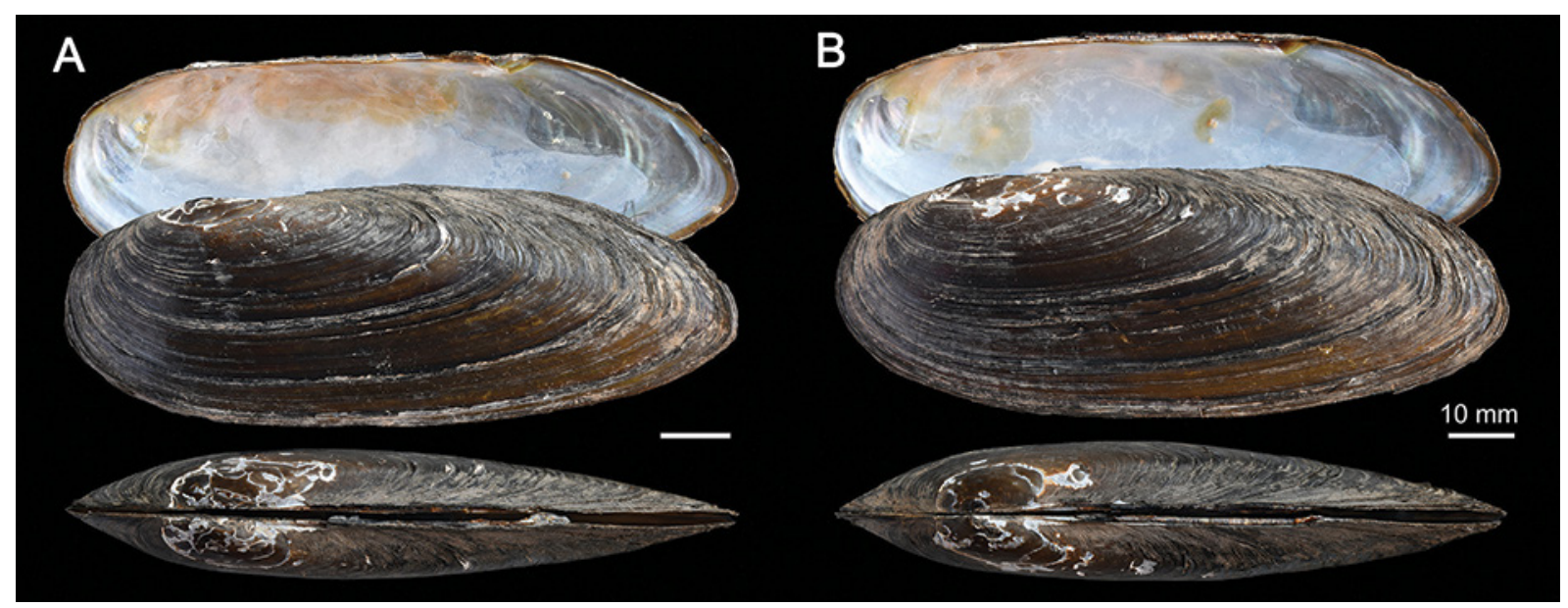

Fig. 4. Namkongnaia inkhavilayi gen. et sp. nov. A. Holotype MUMNH-UNI2831. B. Paratype MUMNH-UNI2836, both from the type localty in Xe Bangfai River, Kammoune Province, Laos. Scale bars: $10 \mathrm{~mm}$. 
Table 3. Shell measurements for the type series of Namkongnaia inkhavilayi gen. et sp. nov. Measurements in millimetres $(\mathrm{mm})$.

\begin{tabular}{llccc}
\hline Type status & Specimen voucher & Shell length & Shell height & Shell width \\
\hline Holotype & MUMNH-UNI2831 & 102.18 & 35.82 & 18.00 \\
Paratype & MUMNH-UNI2832 & 79.00 & 26.23 & 13.62 \\
Paratype & MUMNH-UNI2833 & 91.31 & 29.03 & 16.36 \\
Paratype & MUMNH-UNI2834 & 80.89 & 28.41 & 14.64 \\
Paratype & MUMNH-UNI2835 & 88.74 & 31.12 & 16.31 \\
Paratype & MUMNH-UNI2836 & 101.76 & 37.16 & 19.06 \\
\hline
\end{tabular}

to UNI2829, UNI2669 - 5 shells; Grand Lacs; MNHN-MP-3156 • 2 shells; Phnom Penh; MNHNMP-3158 4 shells; Cambodge; MNHN-MP-3163, MNHN-MP-3171.

\section{Differential diagnosis}

This species resembles the type species, but it can be distinguished by the relatively smaller size with a shell length of 67.0-81.0 mm (vs 80.9-102.2 mm), anterior adductor muscle scar placed near the dorsal margin (vs relatively far from the dorsal margin), adductor muscle scar relatively deep for the thin shell (vs shallower, although thicker shell), nacre yellowish (vs whitish), anterior margin rounded and little shouldered (vs wider and not shouldered), and the anterior portion of the dorsal margin somewhat lower than the posterior (vs at the same level in both anterior and posterior portions).

\section{Description}

Shell medium-sized, rather thin, narrow and elongated $(\mathrm{H} / \mathrm{L}$ ratio $=0.39)$, very inequilateral, compressed. Dorsal margin straight; somewhat lower anteriorly than posteriorly. Umbonal area eroded, not elevated. Anterior margin round, little shouldered; posterior margin elongated, somewhat pointed. Ventral margin almost straight, or minutely concave in the middle in old specimens, posteriorly slightly curved upward. Posterior ridges low, wide and obtuse, not prominent. Periostracum thin, yellowish to dark brown, the eroded part coppery-brown. Shell surface with fine growth lines. Ligament very narrow. Hinge without dentition, posterior end of the hinge structure with V-shaped fossette. Anterior adductor muscle scar placed near the dorsal margin, relatively deep for the thin shell, ovate, fused with pedal retractor muscle scars; posterior adductor muscle scars very shallow, almost invisible. Pallial line very faint. Nacre yellowish with creamy tint near the umbo.

\section{Additional description}

Examination of the soft body of newly collected specimens in this study yielded additional description of the animal: excurrent aperture smooth, shorter than incurrent; incurrent with 1-2 rows of conical papillae, similar in length; small epithelial folds form a fused bridge separating excurrent and incurrent aperture; gills elongated and slightly ribbed; anterior margin of inner gills slightly longer and wider than that of outer gills. However, no brooding specimens were available to examine glochidia.

\section{Distribution}

This species is restricted to Tonle Sap Lake and its tributaries in Cambodia. Its distribution probably reaches the headwater of Tonle Sap basin in eastern Thailand (Brandt 1974).

\section{Habitat}

This species was recorded in mud substrate in still sections of rivers or in lentic habitat, i.e., ponds and lakes (Morelet 1875; Morlet 1889; Brandt 1974). 


\section{Remarks}

This species has been noted for its rarity (Brandt 1974; Ng et al. 2020). Only a few lots are available in museum collections. We obtained additional fresh materials from the Kampong Kdei River, Siem Reap Province. These specimens resemble the syntype MNHN-MP-3150 (Fig. 5D). The only detected variations are less erosion of the umbo area and more yellowish-brown colour of the periostracum. Morelet (1875) described Anodonta lemeslei based on specimens collected by M. Le Mesle. The figured specimen is eroded, with a concave ventral margin (Fig. 5B-C), while another
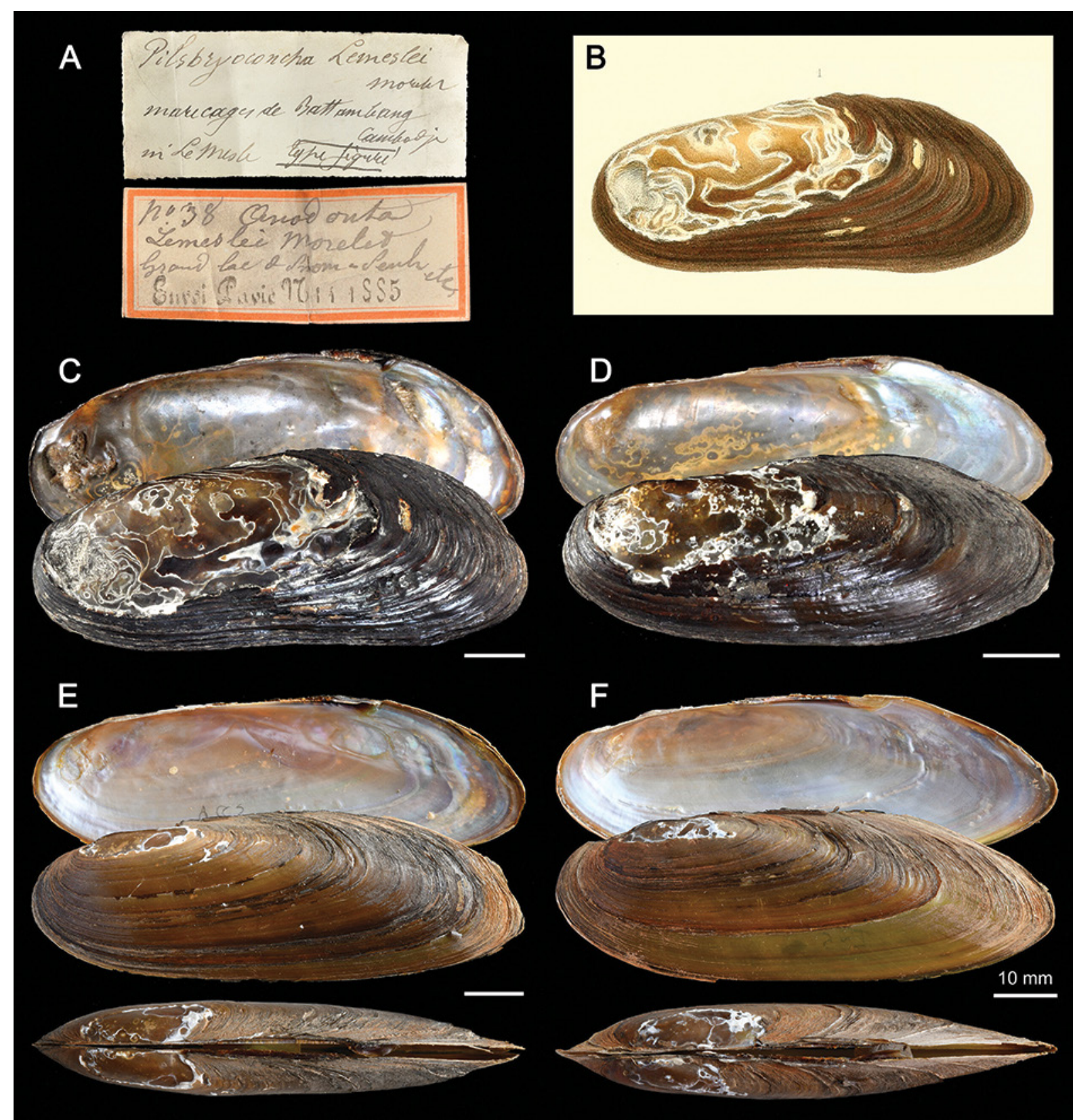

Fig. 5. Namkongnaia lemeslei gen. et comb. nov. A. Labels associated with the syntype lot. B. Original figure (after Morelet 1875: pl. 14 fig. 1). C-D. Syntype MNHN MP 3150 (photographs by V. Heros and M. Caballer) from Battambang Province, Cambodia. E. Specimen MUMNH-UNI2669. F. Specimen MUMNH-UNI2829 from Kampong Kdei River, Siem Reap Province, Cambodia. Scale bars: $10 \mathrm{~mm}$. 
shell has a relatively parallel shell and a straight ventral margin (Fig. 5D). Morelet (1875) identified the ventrally concave specimens as fully-grown individuals, while the ventrally straight specimens were considered to be young individuals. The concavity trait is quite unusual for species that live in stagnant water habitats. Nevertheless, some specimens from Tonle Sap Lake (MNHN-MP-3156) also show the characteristic of a concave ventral margin. However, all of our specimens have a straight ventral margin. This raises some suspicions about the existence of both variations. In this study, we retain both variations as the same species until topotype specimens with concave ventral margin are available for DNA analysis.

Apart from a ventral margin, other morphological variations are also observed. The posterior ends of some specimens are more or less rounded than others. Crosse \& Fischer (1876) noted that some specimens from Cambodia are narrower and more elongated than the type figure. The posterior dorsal margin in some specimens is also somewhat higher. Morelet (1875) noted that one of his type specimens is undoubtedly similar to Anodonta schomburgki Martens, 1860 [= Pilsbryoconcha compressa (Martens, 1860)]. However, it is more or less narrow, and the high posterior cannot be considered a posterior wing as in Anodonta schomburgki Martens, 1860.

Several records and specimens previously identified as Pilsbryoconcha lemeslei have been examined and listed in this species. However, a specimen from Khanh Hoa, Vietnam, is conchologically different and does not belong to this species (Thach 2007; Do et al. 2018); rather, it is probably a species of Pilsbryoconcha. This specimen shows more or less curved ventral margin and relatively wider shell.

Similarly, the DNA sequence of specimen assigned to Pilsbryoconcha lemeslei by Bolotov et al. (2020) and Konopleva et al. (2021) is recovered as monophyletic within the Pilsbryoconcha, together with specimens of Pilsbryoconcha exilis from Java, Indonesia (type species) and Pilsbryoconcha linguaeformis, another sympatric species with Namkongnaia lemeslei gen. et comb. nov., from Tonle Sap Lake, in our phylogenetic analyses. However, without examination of the specimen mentioned in Bolotov et al. (2020) and Konopleva et al. (2021), it can only be classified to the genus Pilsbryoconcha.

\section{Discussion}

Our morphological and molecular analyses strongly suggest that freshwater mussels that have long been recognized as 'Pilsbryoconcha lemeslei' from the Mekong River Basin represent a new genus in Pseudodontini. These mussels are morphologically distinct from all other genera by having narrow, elongated, and less inflated shell. Additionally, the ancient divergence (approximately 49.3 Mya; Fig. 2) and large genetic distances from other genera (11.02-12.42\% uncorrected COI p-distance; Table 2) also support it as a distinct genus. The discovery of a new mussel genus from Southeast Asia, and especially from the Mekong River Basin, is not unexpected since several new genera and a dozen new species were discovered during the last decade (Kongim et al. 2015; Jeratthitikul et al. 2019a; Konopleva et al. 2019, 2021; Bolotov et al. 2020; Pfeiffer et al. 2021).

The new genus shares shell characteristics with other genera in Pseudodontini by having a V-shaped fossette at the posterior end of the hinge structure, and absent or reduced pseudocardinal teeth (Brandt 1974; Lopes-Lima et al. 2017). Another distinct morphological character of the tribe is a double-looped or W-shaped sculpture on the umbonal area (Lopes-Lima et al. 2017). Unfortunately, the umbonal area of all specimens from either the type species or specimens of Namkongnaia lemeslei gen. et comb. nov. is heavily eroded, even in young specimens. Therefore, we are unable to confirm this character for the new genus. In the same way, we were unable to examine the glochidia of the new genus, since no brooding individuals were collected in this study. Nevertheless, the glochidia of the new genus are most likely present as an unhooked and semi-elliptical structure, which is the general shape of glochidia among the Gonideinae (Pfeiffer \& Graf 2015; Lopes-Lima et al. 2017). 
Phylogenetic analyses in this study reveal a close relationship between the new genus and Monodontina, although with moderate support by only the $\mathrm{BI}$ analysis $(\mathrm{BPP}=0.97$; Fig. 1$)$. As far as we know, the only shared feature among members of the new genus and Monodontina is the presence of a V-shaped fossette at the posterior end of the hinge structure on the inner surface of the shell. Monodontina differs from the new genus by its ovate to obovate shell with obtuse pseudocardinal teeth (Conrad 1853). However, some species have relatively weak and flattened pseudocardinal teeth, although never absent (Bolotov et al. 2020). Future investigation to confirm the sister relationship between them should include longer sequences and additional gene fragments, or incorporate more informative molecular markers, such as mitogenomic or nuclear genomic data, which have been successfully used in the phylogenetic study of freshwater mussels (Pfeiffer et al. 2019; Froufe et al. 2020; Zieritz et al. 2020).

On the contrary, the new genus is similar in conchology to Pilsbryoconcha, another widespread genus in rivers of Indochina. Both genera share an elongated and laterally compressed shell and completely absent or very reduced pseudocardinal teeth (Brandt 1974). They also have a rounded anterior end with a straight dorsal margin, while other genera in Pseudodontini have a somewhat concave dorsal margin around the position of pseudocardinal teeth. Because of several shared shell characters, the new genus thus has been hidden in the name "Pilsbryoconcha lemeslei (Morelet, 1875)" for more than a hundred years (Simpson 1914; Haas 1969a; Brandt 1974; Graf \& Cummings 2007, 2021a; Zieritz et al. 2018; Ng et al. 2020). The present molecular phylogenetic analysis recovers both genera as a distinct clade (Figs 1-2) and with a deep divergence of $12.41 \%$ uncorrected COI p-distance (Table 2). Our phylogenetic analysis included the type species, Pilsbryoconcha exilis, from Java, Indonesia, which is assumed to be the the type locality (Graf \& Cummings 2021b). In addition, both genera are distinctly separated by several shell characters. The new genus has a narrower shell, with a lower posterior dorsal margin and an almost straight ventral margin. In contrast, Pilsbryoconcha s. str. is wider, elongate linguiform shaped, with a higher dorsal margin and slightly arched ventral margin (Brandt 1974). Some species of Pilsbryoconcha exhibit a high dorsal margin, creating a posterior wing, such as Pilsbryoconcha linguaeformis (Morelet, 1875) from Tonle Sap Lake (Ng et al. 2020).

Pseudodontini is divided into two subtribes, Pseudodontina and Pilsbryoconchina. These two subtribes exhibit a deep genetic divergence from each other, with an average genetic distance of $12.5 \%$ uncorrected COI p-distance and estimated at about 91.9 Mya (95\% HPD $=67.8-116.9$ Mya) (Fig. 6). In the present-day sense (i.e., Graf \& Cummings 2021a), Pseudodontina is a monotypic clade consisting of thirteen valid species from western Indochina rivers, the Yangtze River Basin in China, and northern Vietnam (Graf \& Cummings 2021b). In contrast, Pilsbryoconchina comprises at least six genera and is distributed mainly in the Mekong River and Chao Phraya River basins, the Malay Peninsula, and southern Sunda islands (Graf \& Cummings 2021b). Such a deep divergence is consistent with the division of freshwater biogeography of mainland Southeast Asia into the western Indochina and Sundaland subregions (Bolotov et al. 2020). The separation of two subtribes and later a rapid diversification of genera within Pilsbryoconchina may be a consequence of the palaeo-drainage rearrangement of the large rivers in East Asia as a result of the Cenozoic uplift of the Tibetan Plateau (Wang et al. 2012; Zhang et al. 2019), and in concert with favourable climatic and hydrological conditions in the early Palaeogene (Carmichael et al. 2017), followed by range fragmentation during the abrupt climate change at the Eocene-Oligocene boundary (Buerki et al. 2013). This coincides with the divergence time estimation in this study, which suggests rapid radiation events of the Pilsbryoconchina genera approximately during the Late Cretaceous to Eocene times (mean age $=70.8-49.3$ Mya). The common ancestor of the palaeo-Mekong Gonideinae may have separated from the palaeo-Yangtze drainage in the Albian-Cenomanian times (Froufe et al. 2020), and had subsequent radiations in the palaeo-Mekong River Basin in the Late Cretaceous or Paleocene (Bolotov et al. 2017a, 2017b; Zieritz et al. 2020). 
The new genus consists of two well-defined clades with a deep divergence of $5.10 \%$ uncorrected COI p-distance, and are recognized here as two distinct species. These two species are separated by a deep genetic divergence and are distributed in different geographical drainages. Namkongnaia inkhavilayi gen. et sp. nov. is distributed in tributaries in the Middle Mekong River Basin in Laos and the Korat Plateau, Thailand, while N. lemeslei gen. et comb. nov. is found in Tonle Sap Lake and its tributaries in Cambodia (Fig. 3). The separation of closely related taxa between the Middle Mekong River and Lower Mekong River basins is well documented in other unionid mussels. Almost all the examined genera display this biogeographic pattern (Pfeiffer et al. 2018, 2021; Muanta et al. 2019), suggesting a shared biogeographic history among these taxa.

This study included museum specimens collected from Huai Tadjek, Nang Rong and, Mun River basins on Korat Plateau, Thailand (SMF-220822) for N. inkhavilayi gen. et sp. nov. These specimens agree well with our new species (Brandt 1974: pl. 18 fig. 22). However, they show some variation by having a rather shorter but wider shell and a relatively rounded ventral margin. Unfortunately, we failed to obtain fresh material from this population, and therefore cannot test for its genetic and phylogenetic entity. Nevertheless, freshwater mussels from the Mun River Basin generally show a deep genetic divergence from other parts of the Mekong River Basin (i.e., Songkhram River Basin in the northern Korat Plateau and Tonle Sap Basin in the Lower Mekong River Basin). Usually, they are represented as distinct species (Pfeiffer et al. 2018, 2021; Jeratthitikul et al. 2019b; Muanta et al. 2019). Therefore, there is a possibility that the population from the Mun River Basin is a different species from the currently assigned $N$. inkhavilayi gen. et sp. nov.

Similarly, several specimens in the museum collection were collected from the Chao Phraya River basin and provisionally identified as 'Pilsbryoconcha lemeslei' (i.e., USNM-786217, SMF-BR2663, and ANSP-H19041). These specimens have an elongated and narrow shell which is the diagnostic characteristic of this new genus, but possess some differentiated characters by having a minute concave ventral margin and truncated posterior margin with a pointed posterior end. These specimens are also waiting further confirmation. Therefore, after DNA examination of the two populations in question, the number of members in the new genus will likely increase.

\section{Acknowledgments}

We thank K. Inkhavilay, K. Wisittikoson, A. Fanka, N. Wutthituntisil, S. Chhuoy, and T.H. Ng for their assistance in collecting samples. We extend our thanks to D. Anderson for grammar checking and comments, V.T. Do for providing literature, and V. Heros and M. Caballer, from Muséum national d'Histoire naturelle (2018 RECOLNAT-ANR-11-INBS-0004) for shell photographs. The animal uses in this study have been approved by the Faculty of Science, Mahidol University Animal Care and Use Committee, SCMU-ACUC (MUSC63-026-534). The permission for collecting data in Cambodia was granted by the Inland Fisheries Research and Development Institute (IFReDI) of the Fisheries Administration Ministry of Agriculture, Forestry and Fisheries of Cambodia. This study was financially supported by SUT Research and Development Fund (IRD1-104-64-12-16).

\section{Disclosure statement}

No potential conflict of interest is reported by the authors.

\section{References}

Abell R., Thieme M.L., Revenga C., Bryer M., Kottelat M., Bogutskaya N., Coad B., Mandrak N., Balderas S.C., Bussing W., Stiassny M.L.J., Skelton P., Allen G.R., Unmack P., Naseka A., Ng R., Sindorf N., Robertson J., Armijo E., Higgins J.V., Heibel T.J., Wikramanayake E., Olson D., López H.L., Reis R.E., Lundberg J.G., Sabaj Pérez M.H. \& Petry P. 2008. Freshwater ecoregions of the World: 
A new map of biogeographic units for freshwater biodiversity conservation. BioScience 58 (5): $403-$ 414. https://doi.org/10.1641/B580507

AVMA 2020. AVMA guidelines for the euthanasia of animals. American Veterinary Medical Association. Available from https:/www.avma.org/sites/default/files/2020-01/2020-Euthanasia-Final-1-17-20.pdf [accessed 12 May 2021].

Bolotov I.N., Kondakov A.V., Vikhrev I.V., Aksenova O.V., Bespalaya Y.V., Gofarov M.Y., Kolosova Y.S., Konopleva E.S., Spitsyn V.M., Tanmuangpak K. \& Tumpeesuwan S. 2017a. Ancient river inference explains exceptional oriental freshwater mussel radiations. Scientific Reports 7: 2135.

https://doi.org/10.1038/s41598-017-02312-z

Bolotov I.N., Vikhrev I.V., Kondakov A.V., Konopleva E.S., Gofarov M.Y., Aksenova O.V. \& Tumpeesuwan S. 2017b. New taxa of freshwater mussels (Unionidae) from a species-rich but overlooked evolutionary hotspot in Southeast Asia. Scientific Reports 7 (1): 11573.

https://doi.org/10.1038/s41598-017-11957-9

Bolotov I.N., Pfeiffer J.M., Konopleva E.S., Vikhrev I.V., Kondakov A.V., Aksenova O.V., Gofarov M.Y., Tumpeesuwan S. \& Win T. 2018. A new genus and tribe of freshwater mussel (Unionidae) from Southeast Asia. Scientific Reports 8 (1): 10030. https://doi.org/10.1038/s41598-018-28385-y

Bolotov I.N., Konopleva E.S., Vikhrev I.V., Gofarov M.Y., Lopes-Lima M., Bogan A.E., Lunn Z., Chan N., Win T., Aksenova O.V., Tomilova A.A., Tanmuangpak K., Tumpeesuwan S. \& Kondakov A.V. 2020. New freshwater mussel taxa discoveries clarify biogeographic division of Southeast Asia. Scientific Reports 10 (1): 6616. https://doi.org/10.1038/s41598-020-63612-5

Bouckaert R., Vaughan T.G., Barido-Sottani J., Duchêne S., Fourment M., Gavryushkina A., Heled J., Jones G., Kühnert D., De Maio N., Matschiner M., Mendes F.K., Müller N.F., Ogilvie H.A., du Plessis L., Popinga A., Rambaut A., Rasmussen D., Siveroni I., Suchard M.A., Wu C.H., Xie D., Zhang C., Stadler T. \& Drummond A.J. 2019. BEAST 2.5: An advanced software platform for Bayesian evolutionary analysis. PLoS Computational Biology 15 (4): e1006650. https://doi.org/10.1371/journal.pcbi.1006650

Brandt R.A.M. 1974. The non-marine aquatic Mollusca of Thailand. Archiv für Molluskenkunde 105: $1-423$.

Buerki S., Forest F., Stadler T. \& Alvarez N. 2013. The abrupt climate change at the Eocene-Oligocene boundary and the emergence of South-East Asia triggered the spread of sapindaceous lineages. Annals of Botany 112 (1): 151-160. https://doi.org/10.1093/aob/mct106

Carmichael M.J., Inglis G.N., Badger M.P.S., Naafs B.D.A., Behrooz L., Remmelzwaal S., Monteiro F.M., Rohrssen M., Farnsworth A., Buss H.L., Dickson A.J., Valdes P.J., Lunt D.J. \& Pancost R.D. 2017. Hydrological and associated biogeochemical consequences of rapid global warming during the Paleocene-Eocene Thermal Maximum. Global and Planetary Change 157: 114-138. https://doi.org/10.1016/j.gloplacha.2017.07.014

Coates D., Poeu O., Suntornratana U., Tung N.T. \& Viravong S. 2003. Biodiversity and Fisheries in the Lower Mekong Basin. Mekong Development Series no. 2. Mekong River Commission, Phnom Penh. Available from https://www.mrcmekong.org/assets/Publications/report-management-develop/MekDev-No2-Mek-River-Biodiversityfiisheries-in.pdf [accessed 12 May 2021].

Conrad T.A. 1853. A synopsis of the family of Naïades of North America, with notes, and a table of some of the genera and sub-genera of the family, according to their geographical distribution, and descriptions of genera and sub-genera. Proceedings of the Academy of Natural Sciences of Philadelphia 6: 243-269. Available from https://www.biodiversitylibrary.org/page/1779779 [accessed 12 May 2021]. 
Crosse H. \& Fischer P. 1876. Mollusques fluviatiles, recueillis au Cambodge, par la mission scientifique francaise de 1873. Journal de Conchyliologie 24: 313-342. Available from https://www.biodiversitylibrary.org/page/16071628 [accessed 12 May 2021].

Darriba D., Taboada G.L., Doallo R. \& Posada D. 2012. jModelTest 2: more models, new heuristics and parallel computing. Nature Methods 9 (8): 772. https://doi.org/10.1038/nmeth.2109

Do V.T., Tuan L.Q. \& Bogan A.E. 2018. Freswater mussels (Bivalvia: Unionida) of Vietnam: diversity, distribution, and cobservation status. Freshwater Mollusk Biology and Conservation 21: 1-18.

https://doi.org/10.31931/fmbc.v21i1.2018.1-18

Drummond A.J., Ho S.Y.W., Phillips M.J. \& Rambaut A. 2006. Relaxed phylogenetics and dating with confidence. PLoS Biology 4 (5): e88. https://doi.org/10.1371/journal.pbio.0040088

Folmer O., Black M., Hoeh W., Lutz R. \& Vrijenhoek R. 1994. DNA primers for amplification of mitochondrial cytochrome c oxidase subunit I from diverse metazoan invertebrates. Molecular Marine Biology and Biotechnology 3 (5): 294-299.

Fonseca M.M., Lopes-Lima M., Eackles M.S., King T.L. \& Froufe E. 2016. The female and male mitochondrial genomes of Unio delphinus and the phylogeny of freshwater mussels (Bivalvia: Unionida). Mitochondrial DNA Part B 1 (1): 954-957. https://doi.org/10.1080/23802359.2016.1241677

Frierson L. 1927. A Classified and Annotated Check List of the North American Naiades. Baylor University Press, Waco, Texas.

Froufe E., Bolotov I.N., Aldridge D.C., Bogan A.E., Breton S., Gan H.M., Kovitvadhi U., Kovitvadhi S., Riccardi N., Secci-Petretto G., Sousa R., Teixeira A., Varandas S., Zanatta D., Zieritz A., Fonseca M.M. \& Lopes-Lima M. 2020. Mesozoic mitogenome rearrangements and freshwater mussel (Bivalvia: Unionoidea) macroevolution. Heredity 124 (1): 182-196. https://doi.org/10.1038/s41437-019-0242-y

Graf D.L. \& Cummings K.S. 2007. Review of the systematics and global diversity of freshwater mussel species (Bivalvia: Unionoida). Journal of Molluscan Studies 73 (4): 291-314. https://doi.org/10.1093/mollus/eym029

Graf D.L. \& Cummings K.S. 2021a. A 'big data' approach to global freshwater mussel diversity (Bivalvia: Unionoida), with an updated checklist of genera and species. Journal of Molluscan Studies 87 (1). https://doi.org/10.1093/mollus/eyaa034

Graf D.L. \& Cummings K.S. 2021b. The freshwater mussels (Unionoida) of the World (and other less consequential bivalves). Available from http://mussel-project.uwsp.edu/index.html [accessed 12 May 2021].

Haas F. 1920. Die Unioniden. In: Küster H.C. (ed.) Systematisches Conchylien-Cabinet von Martini und Chemnitz 9 (pt. 2, h. 52): 289-304. Available from https://www.biodiversitylibrary.org/page/34419468 [accessed 12 May 2021].

Haas F. 1969a. Superfamilia Unionacea. In: Martens R. \& Hennig W. (eds) Das Tierreich, Lieferung 88. Walter de Gruyter, Berlin.

Haas F. 1969b. Superfamily Unionacea Fleming, 1828. In: Moore R.C. (ed.) Treatise on Invertebrate Paleontology: N411-N470. Geological Society of America and the University of Kansas, Lawrence, Kansas.

Huang X.C., Su J.H., Ouyang J.X., Ouyang S., Zhou C.H. \& Wu X.P. 2019. Towards a global phylogeny of freshwater mussels (Bivalvia: Unionida): Species delimitation of Chinese taxa, mitochondrial phylogenomics, and diversification patterns. Molecular Phylogenetics and Evolution 130: 45-59. https://doi.org/10.1016/j.ympev.2018.09.019 
Huelsenbeck J.P. \& Hillis D.M. 1993. Success of phylogenetic methods in the four-taxon case. Systematic Biology 42 (3): 247-264. https://doi.org/10.1146/annurev.ecolsys.28.1.437

Jeratthitikul E., Phuangphong S., Sutcharit C., Prasankok P., Kongim B. \& Panha S. 2019a. Integrative taxonomy reveals phenotypic plasticity in the freshwater mussel Contradens contradens (Bivalvia: Unionidae) in Thailand, with a description of a new species. Systematics and Biodiversity 17 (2): 134 147. https://doi.org/10.1080/14772000.2018.1554607

Jeratthitikul E., Sucharit C. \& Prasankok P. 2019b. Molecular phylogeny of the Indochinese freshwater mussel genus Scabies Haas, 1911 (Bivalvia: Unionidae). Tropical Natural History 19: 21-36. Available from https://li01.tci-thaijo.org/index.php/tnh/article/view/181195 [accessed 12 May 2021].

Jovelin R. \& Justine J.L. 2001. Phylogenetic relationships within the polyopisthocotylean monogeneans (Platyhelminthes) inferred from partial 28S rDNA sequences. International Journal for Parasitology 31 (4): 393-401. https://doi.org/10.1016/S0020-7519(01)00114-X

Kang B. \& Huang X. 2021. Mekong fishes: Biogeography, migration, resources, threats, and conservation. Reviews in Fisheries Science \& Aquaculture: 1-38. https://doi.org/10.1080/23308249.2021.1906843

Köhler F., Seddon M., Bogan A.E., Do V.T., Sri-Aroon P. \& Allen D. 2012. The status and distribution of freshwater molluscs of the Indo-Burma region. In: Allen D.J., Smith K.G. \& Darwall W.R.T. (eds) The Status and Distribution of Freshwater Biodiversity in Indo-Burma: 66-88. IUCN, Cambridge.

Kongim B., Sutcharit C. \& Panha S. 2015. Cytotaxonomy of unionid freshwater mussels (Unionoida, Unionidae) from northeastern Thailand with description of a new species. ZooKeys 514: 93-110. https://doi.org/10.3897/zookeys.514.8977

Konopleva E.S., Bolotov I.N., Spitsyn V.M., Kondakov A.V., Gofarov M.Y. \& Vikhrev I.V. 2019. A new Contradens from Laos (Bivalvia: Unionidae: Contradentini). Ecologica Montenegrina 24: 25-31. https://doi.org/10.37828/em.2019.24.5

Konopleva E.S., Bolotov I.N., Pfeiffer J.M., Vikhrev I.V., Kondakov A.V., Gofarov M.Y., Tomilova A.A., Tanmuangpak K. \& Tumpeesuwan S. 2021. New freshwater mussels from two Southeast Asian genera Bineurus and Thaiconcha (Pseudodontini, Gonideinae, Unionidae). Scientific Reports 11: 8244. https://doi.org/10.1038/s41598-021-87633-w

Kumar S., Stecher G. \& Tamura K. 2016. MEGA7: Molecular Evolutionary Genetics Analysis version 7.0 for bigger datasets. Molecular Biology and Evolution 33 (7): 1870-1874.

https://doi.org/10.1093/molbev/msw054

Lanfear R., Frandsen P.B., Wright A.M., Senfeld T. \& Calcott B. 2016. PartitionFinder 2: New methods for selecting partitioned models of evolution for molecular and morphological phylogenetic analyses. Molecular Biology and Evolution 34 (3): 772-773. https://doi.org/10.1093/molbev/msw260

Larget B. \& Simon D.L. 1999. Markov Chasin Monte Carlo Algorithms for the Bayesian analysis of phylogenetic trees. Molecular Biology and Evolution 16 (6): 750-759.

https://doi.org/10.1093/oxfordjournals.molbev.a026160

Lopes-Lima M., Froufe E., Do V.T., Ghamizi M., Mock K.E., Kebapçı Ü., Klishko O., Kovitvadhi S., Kovitvadhi U., Paulo O.S., Pfeiffer J.M., Raley M., Riccardi N., Şereflişan H., Sousa R., Teixeira A., Varandas S., Wu X., Zanatta D.T., Zieritz A. \& Bogan A.E. 2017. Phylogeny of the most species-rich freshwater bivalve family (Bivalvia: Unionida: Unionidae): Defining modern subfamilies and tribes. Molecular Phylogenetics and Evolution 106: 174-191. https://doi.org/10.1016/j.ympev.2016.08.021

Lopes-Lima M., Burlakova L.E., Karatayev A.Y., Mehler K., Seddon M. \& Sousa R. 2018. Conservation of freshwater bivalves at the global scale: diversity, threats and research needs. Hydrobiologia 810 (1): 1-14. https://doi.org/10.1007/s10750-017-3486-7 
Lydeard C., Mulvey M. \& Davis G.M. 1996. Molecular systematics and evolution of reproductive traits of North American freshwater unionacean mussels (Mollusca: Bivalvia) as inferred from 16S rRNA gene sequences. Philosophical Transactions of the Royal Society of London. Series B: Biological Sciences 351 (1347): 1593-1603. https://doi.org/10.1098/rstb.1996.0143

Miller M.A., Pfeiffer W. \& Schwartz T. 2010. Creating the CIPRES Science Gateway for inference of large phylogenetic trees, 2010. Gateway Computing Environments Workshop (GCE): 1-8.

https://doi.org/10.1109/GCE.2010.5676129

Modell H. 1942. Das natürliche System der Najaden. Archiv für Molluskenkunde 74: 161-191. Available https://www.zobodat.at/pdf/Archiv-fuer-Molluskenkunde_174_0161-0191.pdf [accessed 12 May 2021].

Morelet A. 1875. Séries conchyliologiques: Comprenant l'énumération de Mollusques terrestres et fluviatiles recueillis pendant le cours de différents voyages ainsi que la description de plusieurs espèces nouvelles 4. Klincksieck, Paris. Available from https://www.biodiversitylibrary.org/page/11913380 [accessed 12 May 2021].

Morlet L. 1889. Catalogue des coquilles recueillies, par M. Pavie, dans le Cambodge et le Royaume de Siam, et description d'espèces nouvelles. Journal de Conchyliologie 37 (2): 121-199. Available from https://www.biodiversitylibrary.org/page/16015483 [accessed 12 May 2021].

Muanta S., Jeratthitikul E., Panha S. \& Prasankok P. 2019. Phylogeography of the freshwater bivalve genus Ensidens (Unionidae) in Thailand. Journal of Molluscan Studies 85 (2): 224-231.

https://doi.org/10.1093/mollus/eyz013

Ng T.H., Jeratthitikul E., Sutcharit C., Chhuoy S., Pin K., Pholyotha A., Siriwut W., Srisonchai R., Hogan Z.S. \& Ngor P.B. 2020. Annotated checklist of freshwater molluscs from the largest freshwater lake in Southeast Asia. ZooKeys 958: 107-141. https://doi.org/10.3897/zookeys.958.53865

Ngor P.B., Sor R., Prak L.H., So N., Hogan Z.S. \& Lek S. 2018. Mollusc fisheries and length-weight relationship in Tonle Sap flood pulse system, Cambodia. Annales de Limnologie-International Journal of Limnology 54: 34-10. https://doi.org/10.1051/limn/2018026

Pfeiffer J.M. \& Graf D.L. 2015. Evolution of bilaterally asymmetrical larvae in freshwater mussels (Bivalvia: Unionoida: Unionidae). Zoological Journal of the Linnean Society 175 (2): 307-318. https://doi.org/10.1111/zoj.12282

Pfeiffer J.M., Graf D.L., Cummings K.S. \& Page L.M. 2018. Molecular phylogeny and taxonomic revision of two enigmatic freshwater mussel genera (Bivalvia: Unionidae incertae sedis: Harmandia and Unionetta) reveals a diverse clade of Southeast Asian Parreysiinae. Journal of Molluscan Studies 84 (4): 404-416. https://doi.org/10.1093/mollus/eyy028

Pfeiffer J.M., Breinholt J.W. \& Page L.M. 2019. Unioverse: A phylogenomic resource for reconstructing the evolution of freshwater mussels (Bivalvia, Unionoida). Molecular Phylogenetics and Evolution 137: 114-126. https://doi.org/10.1016/j.ympev.2019.02.016

Pfeiffer J.M., Graf D.L., Cummings K.S. \& Page L.M. 2021. Taxonomic revision of a radiation of Southeast Asian freshwater mussels (Unionidae: Gonideinae: Contradentini+Rectidentini). Invertebrate Systematics 35 (4): 394-470. https://doi.org/10.1071/IS20044

RambautA., DrummondA.J., XieD., Baele G. \& Suchard M.A. 2018. Posterior summarization in Bayesian phylogeneticsusing Tracer 1.7.Systematic Biology67(5):901-904.https://doi.org/10.1093/sysbio/syy032

Ronquist F., Teslenko M., van der Mark P., Ayres D.L., Darling A., Höhna S., Larget B., Liu L., Suchard M.A. \& Huelsenbeck J.P. 2012. MrBayes 3.2: Efficient Bayesian phylogenetic inference and model choice across a large model space. Systematic Biology 61 (3): 539-542. https://doi.org/10.1093/sysbio/sys029 
Simpson C.T. 1914. A Descriptive Catalogue of the Naiades, or Pearly fresh-water mussels. Parts I-III. Bryant Walker, Detroit, Michigan. Available from https://www.biodiversitylibrary.org/page/11344898 [accessed 12 May 2021].

Stamatakis A. 2014. RAxML version 8: A tool for phylogenetic analysis and post-analysis of large phylogenies. Bioinformatics 30 (9): 1312-1313. https://doi.org/10.1093/bioinformatics/btu033

Subba Rao N.V. 1989. Handbook,Freshwater Molluscs of India. Zoological Survey of India, Calcutta, India. Available from http://faunaofindia.nic.in/PDFVolumes/hpg/030/index.pdf [accessed 12 May 2021].

Thach N.N. 2007. Recently Collected Shells of Vietnam. L'Informatore Piceno and N.N.T, Ancona, Italy.

Wang Y., Zheng J., Zhang W., Li S., Liu X., Yang X. \& Liu Y. 2012. Cenozoic uplift of the Tibetan Plateau: Evidence from the tectonic-sedimentary evolution of the western Qaidam Basin. Geoscience Frontiers 3 (2): 175-187. https://doi.org/10.1016/j.gsf.2011.11.005

Whelan N.V., Geneva A.J. \& Graf D.L. 2011. Molecular phylogenetic analysis of tropical freshwater mussels (Mollusca: Bivalvia: Unionoida) resolves the position of Coelatura and supports a monophyletic Unionidae. Molecular Phylogenetics and Evolution 61 (2): 504-514. https://doi.org/10.1016/j.ympev.2011.07.016

Zhang P., Najman Y., Mei L., Millar I., Sobel E.R., Carter A., Barfod D., Dhuime B., Garzanti E., Govin G., Vezzoli G. \& Hu X. 2019. Palaeodrainage evolution of the large rivers of East Asia, and HimalayanTibet tectonics. Earth-Science Reviews 192: 601-630. https://doi.org/10.1016/j.earscirev.2019.02.003

Zieritz A., Bogan A.E., Froufe E., Klishko O., Kondo T., Kovitvadhi U., Kovitvadhi S., Lee J.H., LopesLima M., Pfeiffer J.M., Sousa R., Van Do T., Vikhrev I. \& Zanatta D.T. 2018. Diversity, biogeography and conservation of freshwater mussels (Bivalvia: Unionida) in East and Southeast Asia. Hydrobiologia 810 (1): 29-44. https://doi.org/10.1007/s10750-017-3104-8

Zieritz A., Froufe E., Bolotov I.N., Gonçalves D.V., Aldridge D.C., Bogan A.E., Gan H.M., GomesDos-Santos A., Sousa R., Teixeira A., Varandas S., Zanatta D. \& Lopes-Lima M. 2020. Mitogenomic phylogeny and fossil-calibrated mutation rates for all F- and M-type mtDNA genes of the largest freshwater mussel family, the Unionidae (Bivalvia). Zoological Journal of the Linnean Society: zlaa153. https://doi.org/10.1093/zoolinnean/zlaa153

Manuscript received: 14 May 2021

Manuscript accepted: 2 September 2021

Published on: 22 october 2021

Section editor: Rudy Jocqué

Topic editor: Thierry Backeljau

Desk editor: Fariza Sissi

Printed versions of all papers are also deposited in the libraries of the institutes that are members of the EJT consortium: Muséum national d'histoire naturelle, Paris, France; Meise Botanic Garden, Belgium; Royal Museum for Central Africa, Tervuren, Belgium; Royal Belgian Institute of Natural Sciences, Brussels, Belgium; Natural History Museum of Denmark, Copenhagen, Denmark; Naturalis Biodiversity Center, Leiden, the Netherlands; Museo Nacional de Ciencias Naturales-CSIC, Madrid, Spain; Real Jardín Botánico de Madrid CSIC, Spain; Zoological Research Museum Alexander Koenig, Bonn, Germany; National Museum, Prague, Czech Republic. 